Authors:

1. Abdulrahman Alrabiah (Corresponding Author)

School of ICT, Griffith University Gold Coast, Australia

Email: abdul.alrabiah@griffithuni.edu.au, rabiah2@gmail.com

Address: 64 Bamboo Avenue, Bundall QLD 4217 Australia

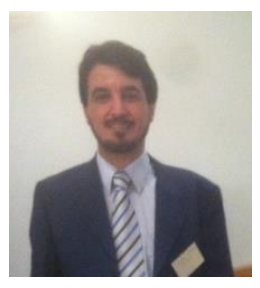

Abdulrahman Alrabiah received the B.Sc. degree in electronic engineering from College of Technology, Riyadh, Saudi Arabia, in 2002, and the M.Sc. degree in business process management, from Queensland University of Technology, Brisbane, Queensland, Australia, in 2011. He is currently a doctoral researcher at Griffith University in the area of business process change. His current research interests include business process management, business process change, regulatory policy implementation and computational models and governance frameworks.

2. Steve Drew

Tasmanian Institute of Learning and Teaching, Academic Division,

University of Tasmania, Australia

Email: steve.drew@utas.edu.au

Address: Private Bag 133, Hobart TAS 7001 Australia

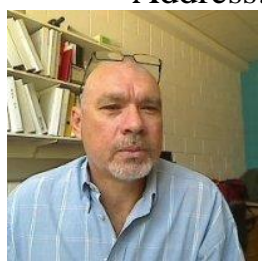

Dr Steve Drew works in Curriculum and Quality at the Tasmanian Institute of Learning and Teaching at University of Tasmania. A past Director of L\&T Griffith Sciences, he is now an Adjunct Research Fellow at Griffith University's Griffith Sciences Group. With a PhD and 20 years of teaching in ICT, the completion of a Graduate Certificate then a research Masters in Higher Education provided a deep knowledge of curriculum design for student engagement with learning and an opportunity to offer credible leadership in L\&T. Whilst undertaking this research and development he was leading the final year ICT capstone Industry Project program and convening the Industry Affiliates Program for Engineering and ICT at the Gold Coast campus. Five years working with Griffith's academic development team provided opportunities to actively foster academic engagement with professional development through its GCHE and FUT programs but most notably through the PRO-Teaching project to create a growing culture of collegial and collaborative L\&T development across the university. Steve also heads a strong $\mathrm{PhD}$ research team looking into the acceptance, adoption and system success stages of technology diffusion in Information Systems areas loosely termed ESystems. This area includes e-Government, e-Commerce, e-Business, e-Health, e-Learning, mobile and ubiquitous computing. 


\title{
Deriving Organisational Business Process Change Factors using the Hierarchical Elicitation Workshop
}

\author{
Abdulrahman Alrabiah \\ School of ICT, Griffith University \\ Gold Coast, Australia
}

\author{
Steve Drew \\ University of Tasmania \\ Hobart, Australia
}

\begin{abstract}
The hierarchical elicitation workshop is a new initiative designed and developed to address common shortcomings in business process change initiatives in organisations, particularly those with tight temporal constraints imposed by exogenous bodies. This paper presents a systematic solution to deal with dramatic BPC under tight temporal constraints in large business and government organisations. In an empirical case study, the hierarchical elicitation workshop is developed and trialed. Based on the Software Engineering Institute's Quality Attribute Workshop methodology, a step-by-step process was carried out to elicit and validate the required BPC factors. Engaging internal stakeholder teams to consider implications for BPC with respect to factors such as organisational objectives and strategies, governance, business process architecture and applications, a prioritised list of change actions was systematically elicited and then implemented. The HEW framework and process was successfully applied to elicit BPC factors in this case study, with an immediate and effective implementation of process change. This paper will be of particular interest to researchers of change management and business development.
\end{abstract}

Keywords: Business Process Change, Business Models, Change Management, Hierarchical Elicitation Workshop (HEW).

Article type: Research paper

\section{Introduction}

Business process change (BPC) is used to bring about radical, incremental or continuous changes in the working mechanisms of organisations, with the help of IT applications (Hansen, Gann, \& Groak, 1998; Jurisch, Cuno, Palka, Wolf, \& Krcmar, 2012; Reijers \& Mansar, 2005). The task of facilitating effective change can be a challenge for the government sector, not least when it comes to enhancing capabilities by introducing new IT applications to re-engineering processes in its operations (Grover \& Otim, 2009; Harmon, 2014; Luo \& Alex Tung, 1999; Stemberger \& Jaklic, 2007). Some government sector organisations are reluctant to adopt technology in carrying out tasks such as BPC (Pateli \& Philippidou, 2011). While a recent survey by Jurisch, Ikas, Wolf, and Krcmar (2013) shows increasing of BPC project implementations in the public sectors. Although the concept of e-government is accepted and practiced in several countries around the world, its adoption and practice, particularly in developing countries, is often viewed as risky (Heeks, 2003; ITU, 2011; Jurisch, Rosenberg, \& Krcmar, 2016; Scholl, 2003). To ensure BPC success, an organisation requires good technical and managerial skills and a significant amount of people who are willing to use information system services (Cameron \& Green, 2015; Langer, 2017; Prattipati, 2003). Contextual considerations are also important while implementing strategies, such as the culture of the place where e-government is being implemented, and the legal and political structure of the state (Martinsons \& Davison, 2007; Nair, Kuppusamy, \& Davison, 2005; Niehaves, Plattfaut, \& Becker, 2013).

\section{Research motivations}

Resolving business process change decisions (BPCDs) in an organisation under tight temporal constraints imposed by exogenous authorities is a critical task (Vakola \& Rezgui, 2000; Zellner, 2013). 
It is made more difficult by the current lack of a systematic foundation in BPC models that incorporates well-defined factors (Majed Al-Mashari, Irani, \& Zairi, 2001; Jurisch et al., 2016). A hierarchical BPC factor elicitation workshop framework and process to facilitate a successful BPC implementation is vital (Cardoso, Almeida, Guizzardi, \& Guizzardi, 2013; Paul, Yeates, \& Cadle, 2014), yet thus far unavailable (Sikdar \& Payyazhi, 2014).

The Hafiz Program in the Kingdom of Saudi Arabia (KSA) was selected as a case study to formulate and test the newly developed BPC factor Hierarchical Elicitation Workshop (HEW) framework to use in BPC implementations. The Hafiz Program is an initiative for resolving growing unemployment problems by providing financial incentives for genuine job seekers (Al-Harbi, 2012; Aluwaisheg, 2012). Hafiz is an Arabic word for 'incentive' and the program provides a living allowance for citizens who are job seekers until they are employed. The program is accessed via a fully automated portal and services a huge pool of applicants totalling more than two million at any time. The Ministry of Labour was asked by a cabinet decree order to implement specific BPC interventions in less than three months to address unemployment welfare challenges. Thus, the project was set on an aggressive BPC path, with the ministry being under complex constraints to address challenges within short temporal dimensions that we refer to in this paper as tight temporal constraints (or TTCs).

Lack of an existing systematic BPC factor elicitation method is foreseen as an issue in BPC theory (Jurisch et al., 2012; Jurisch et al., 2016; William J Kettinger \& Teng, 1998; Paul et al., 2014; Sikdar \& Payyazhi, 2014). In addition, a process to rapidly determine the sources of impediments to change facing a large government organisation, where the time for BPC is critical, was not suitable in the literature.

This paper presents a systematic workshop methodology designed to allow organisations to succeed with the dynamic changes in their daily business process routines (Adesola \& Baines, 2005; Davenport, 1993; Grover \& Kettinger, 2000; Zellner, 2011). Called the 'Business Process Change Factors Hierarchical Elicitation Workshop' (HEW), it allows an organisation to frame the BPC factors through a systematic elicitation workshop with minimal effort, thereby smoothing the path for efficient execution of BPC implementation under TTC (Chakraborty, Sarker, \& Sarker, 2010). From the observations of this case study, most organisations in this operating context would face similar challenges in reacting optimally. Investigation into BPC processes in comparable organisations revealed that there was a common lack of systematic methodology to deal with prompt BPC action in TTC cases.

In this empirical case study, we used the Hierarchical Elicitation Workshop (HEW) as the first step to create our novel Hierarchical Change Management Structure (HCMS) framework, the details of which will be the subject of a following paper. This paper presents the initial steps of the case study and, as an introduction to the study, outlines the use of the HEW and its results. In the remainder of this paper, section 2 reviews the literature on BPC decision making and decision quality. Section 3 proposes the HEW framework and explains its methodology (process). Section 4 illustrates the developed framework phases and the workshop outcome. Finally, section 5 provides concluding remarks including a summary of findings, practical implications, research limitations and recommendations for future work.

\section{Review of literature}

\subsection{Business process change decision making}

In the current environment, the business manager is not directed to a suitable configuration of business processes by the prevailing business process models and management approaches, although decision support systems have a significant role (Harmon, 2014; Pateli \& Philippidou, 2011). Numerous external factors can influence change on business processes, e.g. innovative technologies, compliance with industry standards and government rules, changes in the business field, competitive environment, shareholders' needs, or economic factors pertaining to globalisation (M. Al-Mashari \& Zairi, 1999; Amiyo, 2012; Bandara, Gable, \& Rosemann, 2005; Fan \& Zhao, 2017; Goedertier \& Vanthienen, 2006; 
Grover \& Otim, 2009; Jurisch et al., 2012; Kaplan, Murdock, \& Ostroff, 1991; William J Kettinger \& Teng, 1998; Neumann, 2014; Wang, Medaglia, \& Zheng, 2017).

A change in operating environment may lead to various changes in business strategy, ranging from the launch of small scale automation to mechanisation of an entire process (Soffer, 2005; Thomas, 2008; Wu, Straub, \& Liang, 2015). Many such changes are imposed by exogenous entities including government, regulatory entities and industry standards (Neumann, 2014). The lack of a rigorous decision model and process for BPC introduces ambiguity and lack of clarity surrounding determination of requisite business changes (Afflerbach, Bolsinger, \& Röglinger, 2016; Amiyo, 2012; Grover \& Otim, 2009; Hiatt \& Creasey, 2012). In these cases there can be a failure to deal effectively with factors such as limitations in the decision-making authority of those in leadership roles, uncertainty of flow-on effects of decisions on subsequent business processes (Ariouat, Hanachi, Andonoff, \& Benaben, 2017), likely relationships between process goals and change decisions (Alotaibi \& Liu, 2017; Kavakli \& Loucopoulos, 1999; Rausch \& Anderson, 2011), and limitations of those decisions (Afflerbach et al., 2016; Habjan, Popovic, \& ENGLAND, 2008; Malihi \& Aghdasi, 2014; Rinderle, Reichert, \& Dadam, 2004).

When there is a change in an organisation, irrespective of the level of change, the capability for swift action to enact that change is a basic requirement for productivity and competitiveness (Cameron \& Green, 2015; Goedertier \& Vanthienen, 2006; Grover \& Otim, 2009; Ploesser, Recker, \& Rosemann, 2008). Change efficiency is moderated by an organisation's decision-making processes and hinges on individuals' choices based on trade-off analyses (Kirchmer, 2015; Neumann, 2014). In addition, uncomplicated and straightforward decision-making in organisations is required to reach optimum BPC implementation and to continuously improve services (Luftman, 2015; Malihi \& Aghdasi, 2014; Rausch \& Anderson, 2011; Vakola \& Rezgui, 2000). Therefore, faced with change, organisations benefit from agile decision making and by using a holistic framework that can easily elicit BPC factors (Majed AlMashari et al., 2001; Gong \& Janssen, 2012; Jurisch et al., 2013; Paul et al., 2014; Sikdar \& Payyazhi, 2014).

For process improvement, two levels of BPC have been identified: 'tactical' for process improvement, and 'strategic' for business process reengineering to confront any significant issues or changes imposed by exogenous parties (Bass, Clements, \& Kazman, 2012; Jurisch et al., 2012; Thomas, 2008; Zellner, 2011). This classification, however, is too abstract for optimal BPC decisions which rely also on detailed operational information. Further, Sikdar and Payyazhi (2014); Soffer (2004), concentrate on the effect of change in a process. The idea of the span of a change is introduced, including potential for new inputs or outputs to be produced, and pre-conditions and post-conditions for other actions to be set. In this way diagnosis of the limitations of adjustment efforts and effects of internal and external drivers for change can be pinpointed for optimal BPC (Rosenberg, Jurisch, Schermann, \& Krcmar, 2014; Škerlavaj, Štemberger, \& Dimovski, 2007; Whelan-Berry \& Somerville, 2010).

Currently available business process management tools and techniques (such as Appian, ADKAR, ARIS, TIBCO, Oracle and others) do not adequately address the process of decision-making for optimal BPC in which time, cost, application, process and other parameters are quantifiable and measurable (Grgecic, 2011; Hiatt \& Creasey, 2012; Jurisch et al., 2012; Kaplan et al., 1991; W.J. Kettinger \& Grover, 1995; William J Kettinger \& Teng, 1998). For that reason, Amiyo (2012) undertook valuable research that put stress on a utility to develop a platform in which time to reach BPC decisions was enhanced. The platform provided an interactive application implementing decision science concepts such as the generation of alternatives, and selection of an optimal solution (Rausch \& Anderson, 2011). The generation of alternatives doesn't necessarily result in convergence into an optimal decision; it is important to implement all the constituents of a decision quality chain to achieve an optimal decision (Matheson, 2005; McNamee \& Celona, 2005). The reviewed literature indicates that rigorous decision models for BPC are not well addressed. 


\subsection{Business process change decision quality}

Although BPC is also concerned with introduction of the latest technologies in working environments and integration of jobs in an organisation, its overarching purpose is to fulfil the expectations of customers. Effectively implemented, it gives organisations structure that is flexible, innovative, capable and highly responsive towards its customers (Gong \& Janssen, 2012; Harmon, 2014; Jurisch, 2014; Lee, Strong, Kahn, \& Wang, 2002). Implementation of BPC results in a number of positives to the organisation, which can include employee empowerment, integration of tasks, and task order flexibility (Chang, Levy, \& Powell, 2009; Harmon, 2014; Malhotra, 1998). BPC is used to maximise the production of services that are profitable and modern in nature, reducing unnecessary workloads, and where customers enjoy a single point of contact with a mixture of centralised and decentralised operations as appropriate (Jurisch, 2014).

Business process change procedure is often assisted by qualified BPC consultants (M. Al-Mashari \& Zairi, 1999; Jurisch, Palka, Wolf, \& Krcmar, 2014; W.J. Kettinger, Teng, \& Guha, 1997) to reach optimal outcomes. Consultants provide focus on attaining required results, bring no bias towards decisions taken, understand the working mechanism of the procedure, and serve as a communication channel between key stakeholders (Neumann, 2014; Vakola \& Rezgui, 2000). Jurisch et al. (2014) found that more than 50 percent of BPC developments currently used consultants. This low take-up has the potential to lower the capability for success of BPC initiatives. The roles of consultants are decided by the company and may include facilitating roles such as acting as knowledge distributors, or as team members helping other employees carry out procedures correctly (Cadle, Paul, \& Turner, 2010; Harmon, 2010; Magutu, 2010; Zigiaris, 2000).

Installation of a BPC factors hierarchical elicitation framework has the potential to be a straightforward solution that will reduce the risks incurred by dependence on external consultants (Neumann, 2014; Paul et al., 2014). Harmon (2014) indicated several conditions under which implementation of BPC strategy could be implemented. These included establishing new infrastructure requirements, establishing networks among prominent working bodies of the organisation, and maintenance of information system applications. Thus, a BPC procedure consists of several steps. First is identification of the current problematic areas and the actions being taken to deal with them, second is identification of the processes requiring changes, and third is implementation of the required changes in those processes (Neumann, 2014).

\section{Hierarchical Elicitation Workshop (HEW) and its methodology}

In this section, a systematic method for elicitation of the required organisational BPC factors that facilitate the development of a Hierarchical Change Management Structure (HCMS) framework is presented. The exploratory methodology used in this research paper is based on workshop techniques adopted and adapted to this application from the Quality Attribute Workshop (QAW) of the Software Engineering Institute (Barbacci, 2003).

To construct the HCMS framework, business information must be elicited from all levels of an organisation using a systematic and rigorous methodology (Adesola \& Baines, 2005; William J Kettinger \& Teng, 1998). As such, the HEW was organised to elicit the information systematically by interacting with various stakeholders (Chakraborty et al., 2010; William J Kettinger \& Teng, 1998). To simplify the execution of this workshop, we divided the steps into three phases: pre-engagement, onengagement, and post-engagement. The pre-engagement phase is for the collection of essential preliminary information and documents. The information elicitation workshop constitutes the onengagement phase, and the post-engagement phase is when the initial HCMS is created and constructed. The post-engagement phase (see Figure 1) and its functions are briefly mentioned in this paper. A separate, forthcoming paper will detail the process of formulating optimal BPC decisions using a computational HCMS framework. 
The HEW consists of eight steps, as in Figure 1, and are grouped in three phases, i.e. presentation and elicitation, change management drivers and scenario identification and consolidation and prioritisation arranged to elicit organisational BPC factors information. The first phase consists of four steps, i.e. organisational objectives and strategies, organisational structure and governance, business process architecture and application architecture. The second phase comprises of two steps, i.e. identification of organisational change management drivers and brainstorming of scenario alternatives. The third phase contains of two steps, i.e. scenarios consolidation and scenarios prioritisation. Most of the information is captured in tabular or matrix form to accurately represent the information and its relationships.

The workshop was conducted by the researchers with a change management team (CMT) comprised of stakeholders from different functional groups and hierarchical levels within the organisation (Cadle et al., 2010; Luna-Reyes \& Andersen, 2003; Rosenberg et al., 2014; Stufflebeam, 2001). The CMT members were nominated either by their department or the executives, or recommended by other CMT members. The workshop is designed to systematically elicit BPC factors (Luna-Reyes \& Andersen, 2003). The expected outcome from this workshop is for the organisation's staff to engage with a formal framework for BPC instead of ad-hoc implementation (Neumann, 2014). It was found that this workshop enabled the CMT to follow easy and well defined steps to conduct process change or smooth the development of BPC implementation without the need to know explicit details or to access staff skilled in business process management (Hiatt \& Creasey, 2012; Sikdar \& Payyazhi, 2014). Hence, such a workshop can be conducted in any organisation involving different stakeholders without the prerequisite of specific technical and related knowledge (Cadle et al., 2010; Langer, 2017).

\section{Hierarchical Elicitation Workshop phases}

This section illustrates the three phases that are required to conduct the BPC factors hierarchical elicitation workshop. The process starts with an initial information elicitation phase that gathers the information via CMT members. This on-engagement phase focuses on generating details through presentations, enumeration, driver identification, alternatives generation, consolidation and prioritisation of BPC factors. Information in this section relates to the Hafiz case study introduced earlier. The post-engagement phase is intended to analyse, compute, evaluate, verify and document the HCMS framework. This latter phase will be described here only in sufficient detail to show the relevance of the outputs of the on-engagement phase.

\subsection{Initial information elicitation phase}

Initial information collected from CMT members that assisted us to construct the workshop includes organisational objectives, structure and governance (Alotaibi \& Liu, 2017), vision and mission, strategy, business process architecture, business process to application mapping, organisation performance measurement (OPM) (Huizing, Koster, \& Bouman, 1997), and current BPC decision methodology (Kaplan et al., 1991; Paul et al., 2014). In the case study to be described, the initial information helps to depict the Hafiz organisation's BPC processes. Further, it allows us to understand how the organisation works (Cardoso et al., 2013; Paul et al., 2014; Vakola \& Rezgui, 2000).

\subsection{On-engagement phase}

5.2.1. Organisation objectives and strategies presentation:

In this step, the representative of the executives makes a short presentation about the overall organisational goals, vision, mission, critical success factors, tactics, challenges, risks and change drivers. After the presentation, a 10-20-minute question and answer session was conducted with the representative to verify the elicited information. Table 1 documents the objectives, tactics and measures elicited during the presentation at Hafiz, four of which were verified during the subsequent question and answer session. The four elicited objectives as in Table 1 are 'Resolve unemployment problem', 
'Provide training to bridge market demand', 'Financial incentive to encourage job seeking' and 'Help job seekers to find employment'. Risk related information elicited and evaluated is presented in Table 2. This information comprises the description of the risk, the events triggering the risk, importance and likelihood of occurrence of the risk. 'System unavailable', 'Erroneous candidate evaluation', 'Negative ripple effect', 'Inability to achieve change objectives', 'Quality of data received from agencies', 'Delay in receiving data', 'Financial funding' and 'Technical issues' are examples of the extracted risks. Table 3 documents the key performance indicators (KPIs) of the organisation. This information includes the context of the indicator, i.e. business, technical, operational, or strategic. It also defines the organisational level where this indicator is measured, and the main objectives of the measurement (Huizing et al., 1997; Vakola \& Rezgui, 2000). There were eight identified KPIs such as 'Registration quality', 'Decision quality', 'Training quality', 'Average complaints resolution rate', 'Technical issues resolution rate', 'Employment rate due to Hafiz Program number of tickets', 'Number of endorsed appeals', and 'Number of rejected payments'.

Table 1 Example of Hafiz's Strategic Objectives Methodology Documentation

\begin{tabular}{|c|c|c|c|c|}
\hline Abbr. & Objective & Description & Tactics & Measure \\
\hline RUP & $\begin{array}{l}\text { Resolve } \\
\text { unemployment } \\
\text { problem }\end{array}$ & $\begin{array}{l}\text { The unemployment rate } \\
\text { has grown rapidly recently; } \\
\text { this prioritised this issue as } \\
\text { number } 1\end{array}$ & $\begin{array}{l}\text { Provide intensive training } \\
\text { assistance to find job. } \\
\text { Help MOL to create right labour } \\
\text { policy to reduce unemployment }\end{array}$ & $\begin{array}{l}\text { National } \\
\text { Unemployment } \\
\text { Rate (NUR) }\end{array}$ \\
\hline TBMD & $\begin{array}{l}\text { Provide } \\
\text { training to } \\
\text { bridge market } \\
\text { demand }\end{array}$ & $\begin{array}{l}\text { Basic skills training that the } \\
\text { program offers }\end{array}$ & $\begin{array}{l}\text { Conduct qualitative and quantitative } \\
\text { gap analysis between skills required } \\
\text { by market and job seeker skills }\end{array}$ & $\begin{array}{l}\text { Average } \\
\text { Training } \\
\text { Requirement } \\
\text { (ATRR) }\end{array}$ \\
\hline $\mathrm{FI}$ & $\begin{array}{l}\text { Financial } \\
\text { incentive to } \\
\text { encourage job } \\
\text { seeking }\end{array}$ & $\begin{array}{l}\text { SAR } 2000 \text { Saudi Riyals } \\
\text { that the program pays } \\
\text { monthly to every } \\
\text { beneficiary }\end{array}$ & $\begin{array}{l}\text { Use cutting edge processes and } \\
\text { technologies to facilitate the } \\
\text { evaluation, control and payment } \\
\text { processing of job seekers }\end{array}$ & $\begin{array}{l}\text { Incentive to } \\
\text { Productivity } \\
\text { Ratio (IPR) }\end{array}$ \\
\hline HJSE & $\begin{array}{l}\text { Help job } \\
\text { seekers to find } \\
\text { employment }\end{array}$ & $\begin{array}{l}\text { Hafiz Program has } \\
\text { gateways to link } \\
\text { beneficiaries with private } \\
\text { sector job opportunities }\end{array}$ & $\begin{array}{l}\text { Encourage both public and private } \\
\text { sectors to publish their job } \\
\text { opportunities via Hafiz gateway to } \\
\text { match and offer jobs to } \\
\text { beneficiaries }\end{array}$ & $\begin{array}{l}\text { Hafiz Assisted } \\
\text { Employment } \\
\text { Rate (HAER) }\end{array}$ \\
\hline
\end{tabular}

Table 2 Example of Hafiz's Risks Evaluation

\begin{tabular}{|c|c|c|c|c|}
\hline Risk & Description & Event & $\begin{array}{l}\text { Importanc } \\
\text { e (1=Low- } \\
5=\text { High) }\end{array}$ & Likelihood \\
\hline System unavailability & $\begin{array}{l}\text { The downtime period that the } \\
\text { system is off }\end{array}$ & $\begin{array}{l}\text { Technical \& } \\
\text { environment } \\
\text { problem }\end{array}$ & 5 & Low \\
\hline $\begin{array}{l}\text { Erroneous candidate } \\
\text { evaluation }\end{array}$ & $\begin{array}{l}\text { It's the wrong evaluation process } \\
\text { of a candidate }\end{array}$ & $\begin{array}{l}\text { Coordination } \\
\text { problem }\end{array}$ & 5 & Medium \\
\hline Negative ripple effect & $\begin{array}{l}\text { An action that cause damage } \\
\text { across other processes in the } \\
\text { organisation }\end{array}$ & Decision problem & 5 & High \\
\hline $\begin{array}{l}\text { Inability to achieve } \\
\text { change objectives }\end{array}$ & $\begin{array}{l}\text { The program did not reach the } \\
\text { defined objectives }\end{array}$ & Management & 5 & High \\
\hline $\begin{array}{l}\text { Quality of data } \\
\text { received from } \\
\text { agencies }\end{array}$ & $\begin{array}{l}\text { The quality of the data received } \\
\text { from government agencies must } \\
\text { be accurate or it will not serve } \\
\text { the program needs }\end{array}$ & $\begin{array}{l}\text { Coordination } \\
\text { problem }\end{array}$ & 5 & Medium \\
\hline
\end{tabular}




\begin{tabular}{|c|c|c|c|c|}
\hline Risk & Description & Event & $\begin{array}{c}\text { Importanc } \\
\text { e (1=Low- } \\
\text { 5=High) }\end{array}$ & Likelihood \\
\hline $\begin{array}{l}\text { Delay in receiving } \\
\text { data }\end{array}$ & $\begin{array}{l}\text { The data must be received on } \\
\text { time to process. }\end{array}$ & Timeliness & 4 & Low \\
\hline Financial funding & $\begin{array}{l}\text { Financial funding must be } \\
\text { available to provide job seekers } \\
\text { with funds }\end{array}$ & $\begin{array}{l}\text { Budget/ fund } \\
\text { issues }\end{array}$ & 5 & Low \\
\hline Technical issues & $\begin{array}{l}\text { IT technical difficulties can } \\
\text { cause delays or interruptions in } \\
\text { service and operation }\end{array}$ & $\begin{array}{l}\text { Technical and } \\
\text { operation issues }\end{array}$ & 4 & Medium \\
\hline
\end{tabular}

Table 3 Example of Hafiz's Key Performance Indicators Enumeration

\begin{tabular}{|c|c|c|c|c|}
\hline Indicator & Description & Context & Level & Objective \\
\hline Registration quality & $\begin{array}{l}\text { The output of the } \\
\text { registration process }\end{array}$ & Technical & High & $\begin{array}{l}\text { Measure service and } \\
\text { data level }\end{array}$ \\
\hline Decision quality & $\begin{array}{l}\text { The outcome of good } \\
\text { decisions output }\end{array}$ & Management & High & $\begin{array}{l}\text { Measure productivity } \\
\text { and performance }\end{array}$ \\
\hline Training quality & $\begin{array}{l}\text { The efficiency level of the } \\
\text { training }\end{array}$ & Human Resources & Mid & $\begin{array}{l}\text { Measure the level of } \\
\text { the provided } \\
\text { knowledge }\end{array}$ \\
\hline $\begin{array}{l}\text { Average complaint } \\
\text { resolution rate }\end{array}$ & $\begin{array}{l}\text { The resolved complaint } \\
\text { issues }\end{array}$ & Call Centre & High & $\begin{array}{l}\text { Measure the level of } \\
\text { the succeed } \\
\text { complaint resolution }\end{array}$ \\
\hline $\begin{array}{l}\text { Technical issues } \\
\text { resolution rate }\end{array}$ & $\begin{array}{l}\text { The resolved technical } \\
\text { issues }\end{array}$ & Technical & High & $\begin{array}{l}\text { Measure the level of } \\
\text { the solved technical } \\
\text { issues }\end{array}$ \\
\hline $\begin{array}{l}\text { Employment rate } \\
\text { due to Hafiz } \\
\text { Program }\end{array}$ & $\begin{array}{l}\text { The succeeded } \\
\text { employment through } \\
\text { Hafiz Program }\end{array}$ & Management & High & $\begin{array}{l}\text { Measure } \\
\text { unemployment rate }\end{array}$ \\
\hline Number of tickets & $\begin{array}{l}\text { Number of technical } \\
\text { tickets raised through call } \\
\text { centre }\end{array}$ & Technical & High & $\begin{array}{l}\text { Measure service } \\
\text { level }\end{array}$ \\
\hline $\begin{array}{l}\text { Number of } \\
\text { endorsed appeals }\end{array}$ & $\begin{array}{l}\text { Number of } \\
\text { endorsed/approved } \\
\text { appeals in certain period }\end{array}$ & Management & Mid & $\begin{array}{l}\text { Measure the quality } \\
\text { of data }\end{array}$ \\
\hline $\begin{array}{l}\text { Number of rejected } \\
\text { payments }\end{array}$ & $\begin{array}{l}\text { Number of rejected } \\
\text { payments from banks }\end{array}$ & Finance & High & $\begin{array}{l}\text { Measure the } \\
\text { payment method } \\
\text { performance }\end{array}$ \\
\hline
\end{tabular}

5.2.2. Organisation Structure and Governance:

In this step, the CMT member presents a brief description of the organisational structure and the BPC decision governance. During the presentation, the initial information of Hafiz's organisational structure and BPC decision governance is verified and documented. More detailed information of the BPC decision governance is documented using Table 4 (see Appendix 8.1.1.), that encompasses the description of each role, its responsibility, manager, and the context of the role, such as executive, business, operational or technical. This step is intended to map the organisation structure to the Hafiz functional structure (see Appendices 8. and 8.5). By obtaining this information, executing BPCs becomes much easier and conflicts are eliminated. All tables mentioned below can be found in the appendices to this paper.

5.2.3. Business process architecture presentation:

In this step, a CMT member presents the organisational business process architecture using a formal representation derived from reputable enterprise architecture frameworks such as The Open Group 
Architectural Framework (TOGAF), or John Zachman's Federated Enterprise Architecture (FEA). The first action is to elicit all business processes and document their descriptions, objectives, functional ownerships and importance (see Table 5). Twenty business processes were elicited for example, 'Candidate registration process', 'Candidate approval process', 'Candidate evaluation process', 'Complaints management process', 'Dispute resolution process', 'Beneficiary payment processing' and others. Identification of these business process elements is critical to enable effective mapping to the other elements (Kaplan et al., 1991; Paul et al., 2014; Vakola \& Rezgui, 2000). The information rendered from this presentation is documented using two tables (see Tables 6 and 7). Table 6 maps each business process with the risks enumerated in step 1 of the on-engagement phase. The measurement of each business process is documented in Table 7 .

5.2.4. Application architecture presentation:

The representative of the IT services department presents the higher-level architecture of the applications used for BPC within the organisation. The representative then enumerates the applications, including description and ownership (Table 8). The enumerated applications are: 'Candidate application processing system', 'Payment training management system', 'Payment processing system', 'Coordination \& integration platform', 'Report \& data analysis platform', 'Monitoring \& control system' and 'Hafiz main portal'. Tables 9 and 10 document all related application architecture information required for the construction of the HCMS. Table 9 maps the applications into functional units that directly or indirectly use them. Table 10 maps the application with the business processes, specifying the relationship between applications and the business processes they are implementing.

5.2.5. Identification of organisation change management drivers:

This step enumerates most of the possible external drivers for BPC. In the Hafiz Program case study, this could be a rise in unemployment rate, new e-government initiatives or political issues. The purpose of generating these drivers is to create the initial HCMS, since the drivers are the cornerstone for the HCMS architecture and execution. In this case study, we concentrated only on external drivers because the focus is on tight temporal constraints imposed by exogenous bodies. However, this can also be used to address internal drivers. Tables 11 and 12 document these drivers. Table 11 enumerates the drivers and documents them by defining the driver and specifying the organisation that triggers the driver. There were twelve identified drivers i.e. 'New government policy for unemployment', 'Economic policy' (Human Capital), 'Complaints against the program', 'Proactive improvement', 'Political issues', 'Social and cultural issues', 'Increase in unemployment rate', 'Coordination with other entities', 'Growth in users and services in Hafiz Program', 'Quality of services', 'Change in executives or management', 'Change in technology and infrastructures'. Table 12 maps each driver with the objectives' business processes. This gives the holistic information on how these drivers could affect the business processes and applications. This information will be verified to meet the 'reliable decision information' that is described with the decision quality chain.

5.2.6. Brainstorming scenario based alternatives generation:

This step uses a scenario brainstorming method to generate the alternatives based on the decision quality chain model. In this section, all CMT members were engaged to generate a list of alternatives for each driver using scenarios. For each scenario both the change triggers and decision scenarios are documented in Table 13. This conforms with the requirement of the decision quality chain, by addressing creative and feasible alternatives, sound reasoning, and commitment to action (Kaplan et al., 1991; Paul et al., 2014). At this step, all the information is captured to fully address the decision quality requirements. In the Scenarios Documentation Template (see Appendix 8.2), for each trigger multiple solution alternatives are defined. The template documents the scenario along with their drivers, and the related business processes that are affected by the scenario. During the process of documenting the related business process, the team specified the type of change required for the business process and 
documented on the affect column. This has four possible values: ' $C$ ' for create new, ' $D$ ' for delete, ' $U$ ' for update, and ' $\mathrm{N}$ ' for no change.

5.2.7. Scenarios consolidation:

The scenarios are generated and represented using the tabular templates and Business Process Modelling Notation (BPMN) (see Appendix 3). Similar scenarios are consolidated by another brainstorming session and the facilitator explicitly asks all the CMT members to enumerate a set of scenarios that can be joined together or eliminated due to redundancy. Each candidate set of scenarios to be consolidated is documented using Table 13. After a simple voting process, the scenarios that are qualified for consolidation are joined using a new scenario definition and documented again using Table 14. For instance, expand age benefits, increase the period of benefits and increase training programs scored high priority.

5.2.8. Scenarios prioritisation:

After scenarios are consolidated, they are prioritised using a rigorous voting process. The purpose of the prioritisation is to rank the most important (likely) scenarios while constructing the HCMS. It is labour intensive for large organisations to construct the HCMS from all the scenarios; therefore, the initial HCMS can be constructed from the highly-prioritised scenarios, and implementation of the other scenarios can be deferred and included in a continuous HCMS improvement program. In the voting processes, each member is assigned a 'voting weight' that reflects the importance of their decision based on the organisational governance. Table 15 documents the voting weights assigned to each CMT member. Table 16 records the weighted votes of each CMT member, calculated by the member vote multiplied by their 'voting weight'. A member can vote by assigning minimum 0 and maximum 3 . After the voting process, the scenarios are sorted in descending order of their aggregate weighted votes. Based on the organisational constraints that are elicited in the pre-engagement phase, the CMT can select the most highly-prioritised scenarios for immediate implementation and defer the remainder for later implementation. Each scenario represents an alternative decision for the implementation of a BPC for a given business process.

\subsection{Post-engagement phase}

Post-engagement is intended to analyse, compute, evaluate verify and document the HCMS Framework. The steps include: 'identify business processes causal relationships', 'generate initial HCMS', 'construct Causal Analysis Models (CAMs)', 'compute HCMS values', 'evaluate initial HCMS', 'check anomalies' and 'document HCMS'.

From the previous phases of initial information elicitation and on-engagement, all the required information is formulated and used in the proposed HCMS Framework needed to execute and compute BPC implementation. The HEW has facilitated the formulation of the HCMS through systematic steps. The HCMS as applied to our case study (Hafiz) is a separate topic and will be described elsewhere.

In summary, the steps conducted by the CMT started with using exploratory or growth scenarios to evaluate the initial HCMS and help management to refine changes in scenarios and act proactively before implementing any change management procedures (Hiatt \& Creasey, 2012). Moreover, exploratory or growth scenarios allow organisations to stress the system before running any changes or experiencing growth as well as exploring any ramifications to be tackled in early stages. The evaluation of the initial HCMS requires systematic steps to ensure the best output from the existing structure. Consolidating scenarios allows the CMT to prioritise and aggregate scenarios based on their importance to the organisation, and here the same method is used by observing the outputs and changes in the organisation's business process.

The broad vision of the HEW is to enable organisations to execute BPCs through the Hierarchical Change Management Structure (HCMS). Benefits of HCMS include support to make optimal decisions, 
selecting the best alternatives, minimising cost, time, and risk, and maximising quality of service (Reijers \& Mansar, 2005).

\subsection{Workshop outcome}

The main outcome of this research is the formation of a practical BPC factors elicitation procedural methodology (HEW) through well-defined structured steps. The collection of initial information was important and helpful to understand how the organisation might most effectively execute BPC initiatives. The on-engagement phase is the main stage in this workshop where most of the BPC factors were elicited and prioritised. The HEW systematically extracted and prioritised BPC factors such as organisational objectives and strategies, risks, KPIs, governance, business process architecture and applications, change management drivers. Further, engaging internal stakeholder teams, practitioners or managers on the HEW moved from being ad-hoc to a more formalised process. The hierarchy elicitation procedures simplify the required actions to optimise BPC implementations. The advantages were fruitful for the organisation providing a speed up of the business processes, concentration on improvements, enhanced cost effectiveness, and improved efficiency (Rosenberg et al., 2014). This phase conceptualised the BPC ad-hoc tasks to a formal technique (framework) in a sequential flow of steps. This results in fewer mistakes, standardised BPCs, and less dependency on experts for specific knowledge (Andrade, van der Aa, Leopold, Alter, \& Reijers, 2016). Further, formalising the process of eliciting BPC factors shifts the focus to enhance the outcomes of the BPC rather than becoming mired in traditional processing (Cardoso et al., 2013). The post-engagement phase is designed to analyse, compute, evaluate, verify and document the executable HCMS framework. The next step is to use the developed HEW framework.

The results of using the HEW framework can be summarised as follows: BPC information collection was standardised; BPC factors were elicited by using a consistent methodology; the CMT found that the procedure reduced ambiguity and uncertainty around elicitation of BPC factors, and reduced time and effort; the framework helped to identify team and department roles and tasks (Cadle et al., 2010). Further, an advantage of the HEW process is that the majority of collected information can be captured electronically in an application or web-executable software. 


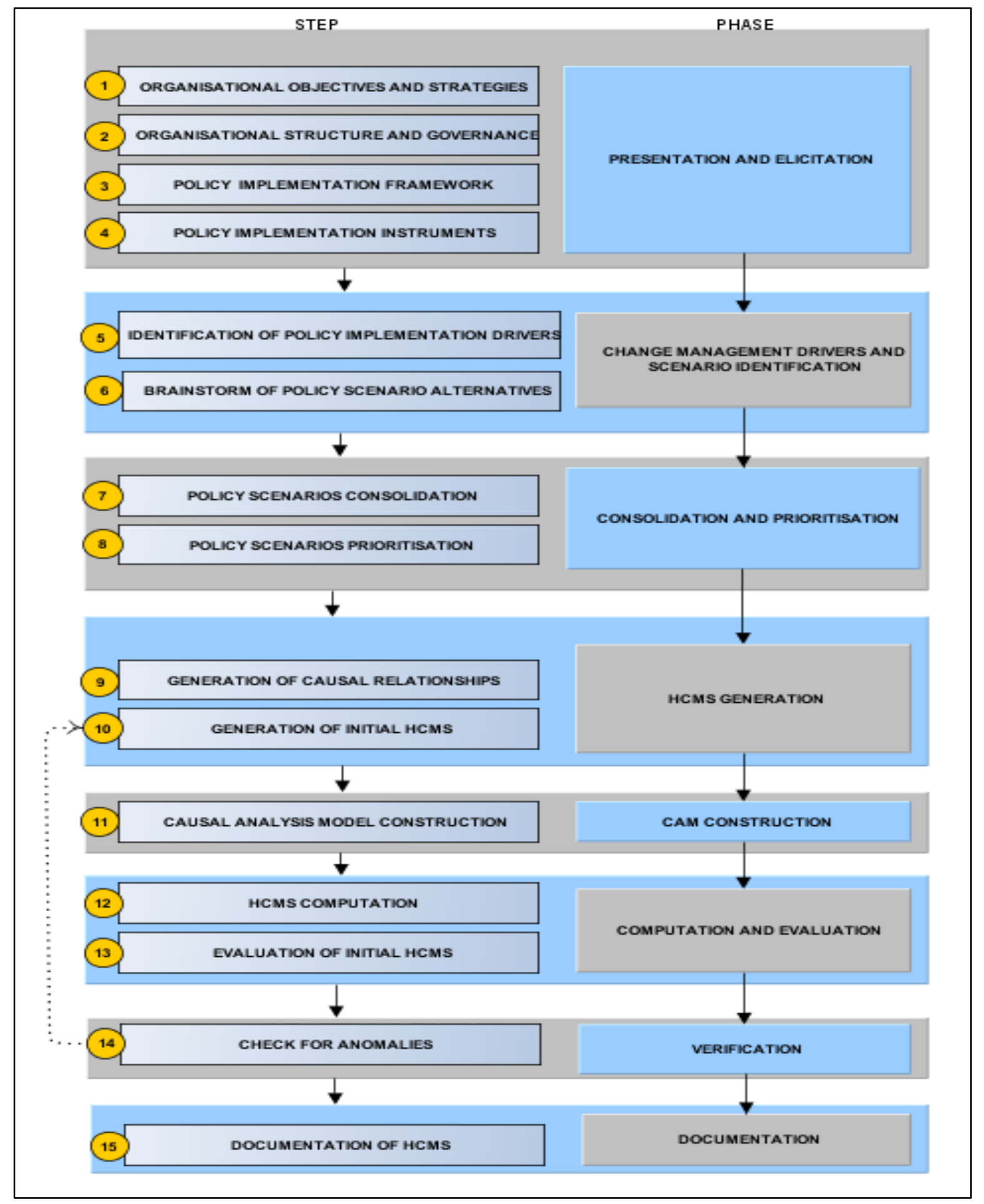

Figure 1 The Hierarchical Elicitation Workshop Framework

\section{Conclusion}

\subsection{Summary of findings}

Literature on BPC decision-making and decision quality was reviewed and consequently led us to recognise the need for a BPC factors elicitation framework to improve the decisions surrounding BPC implementations. As a result, a novel BPC factors elicitation workshop was designed and conducted that was positively received during the conduct of the Hafiz case study. The associated Hierarchical Elicitation Workshop positively impacted BPC implementation in the organisation. Major findings were that the HEW framework simplified the deriving of BPC factors, the organisation gained a formal 
BPC standardisation and elicitation process, knowledge process sharing was enhanced, time and effort was reduced, and BPC roles and responsibilities were clearly identified. Further, the HEW framework systematically structured the BPC elicitation process.

\subsection{Practical implications}

This new structured framework and process for BPC decision making will enable organisations anywhere to implement high priority changes rapidly and effectively. The applied HEW workshop framework constitutes a substantial improvement in reducing effort, time and resources. The practical workshop method ensures that critical BPC factors are extracted in an efficient and effective manner. Factors such as organisational objectives, strategies, risks, performance indicators, structures, governance, business process architecture and applications including scenarios and alternative prioritisation methodologies were systematically elicited. The framework added value to the applied case study and indicated the potential for this methodology to make a significant contribution to shaping and formulating BPC initiatives in any organisation.

\subsection{Research contribution/originality}

The developed HEW framework and elicitation methodology is the authors' novel and original contribution to reduce impediments in the BPC domain, particularly where there are tight temporal constraints. The HEW framework is a new adaptation of the Software Engineering Institute's Quality Attributes Workshop methodology. This adaptation improved BPC factor elicitation in a case study and diminishes a gap in literature on this topic.

\subsection{Research limitation}

This research describes a single case study to present a proof of concept for effective and efficient BPC decision-making in a single organisational context. Proof of concept would be strengthened by application of this innovation in more domains. Further, creating an ontological representation of a hierarchical change management structure to promote cross-organisational HCMS modelling would be an advantage to further validate this framework workshop.

\subsection{Recommendations and future work}

For future work, we recommend the use of the HEW framework in more empirical cases to validate it in the hierarchical change management structure; creating a HEW execution engine to automate the elicitation processes; and, creating an ontological representation of the HEW framework to promote cross-organisational HCMS framework construction and execution. There will be more research going on in that area. 


\section{References}

Adesola, S., \& Baines, T. (2005). Developing and evaluating a methodology for business process improvement. Business Process Management Journal, 11(1), 37-46.

Afflerbach, P., Bolsinger, M., \& Röglinger, M. (2016). An economic decision model for determining the appropriate level of business process standardization. Business Research, 9(2), 335-375.

Al-Harbi, K. (2012). Why will Hafiz aid end this year? Saudi Gazette. [online] http://saudigazette.com.sa/article/2432/What-will-happen-to-Hafiz? Accessed (12 May 2016).

Al-Mashari, M., Irani, Z., \& Zairi, M. (2001). Business process reengineering: a survey of international experience. Business Process Management Journal, 7(5), 437-455.

Al-Mashari, M., \& Zairi, M. (1999). BPR implementation process: an analysis of key success and failure factors. Business Process Management Journal, 5(1), 87-112.

Alotaibi, Y., \& Liu, F. (2017). Survey of business process management: challenges and solutions. Enterprise Information Systems, 11(8), 1119-1153.

Aluwaisheg, A. (2012). Employment incentives should not become a welfare program. Arab News. [online] http://www.arabnews.com/\%5Btermalias-raw\%5D/employment-incentives-shouldnot-become-welfare-program Accessed (10 May 2016).

Amiyo, M. R. (2012). Decision enhancement and business process agility. (PhD Thesis), University of Groningen, Groningen, The Netherlands.

Andrade, E., van der Aa, H., Leopold, H., Alter, S., \& Reijers, H. (2016). Factors Leading to Business Process Noncompliance and its Positive and Negative Effects: Empirical Insights from a Case Study. Paper presented at the 22nd Americas Conference on Information Systems, AMCIS 2016, San Diego, CA, USA, August 11-14, 2016, San Diego, CA, United States.

Ariouat, H., Hanachi, C., Andonoff, E., \& Benaben, F. (2017). A Conceptual Framework for Social Business Process Management. Procedia Computer Science, 112, 703-712.

Bandara, W., Gable, G. G., \& Rosemann, M. (2005). Factors and measures of business process modelling: model building through a multiple case study. European Journal of Information Systems, 14(4), 347-360.

Barbacci, M. R., Ellison, R. J., Lattanze, A., Stafford, J., Weinstock, C. B., \& Wood, W. (2003). Quality Attribute Workshops (QAWs). Retrieved from Pittsburgh: http://resources.sei.cmu.edu/library/asset-view.cfm?assetID=6687 Accessed (17 February 2016).

Bass, L., Clements, P., \& Kazman, R. (2012). Software Architecture in Practice, Third Edition (3 ed.): Addison-Wesley, 2012.

Cadle, J., Paul, D., \& Turner, P. (2010). Business analysis techniques: 72 essential tools for success: BCS, The Chartered Institute.

Cameron, E., \& Green, M. (2015). Making sense of change management: A complete guide to the models, tools and techniques of organizational change: Kogan Page Publishers, 2015.

Cardoso, E., Almeida, J. P. A., Guizzardi, R. S., \& Guizzardi, G. (2013). A method for eliciting goals for business process models based on non-functional requirements catalogues. Frameworks for Developing Efficient Information Systems: Models, Theory, and Practice: Models, Theory, and Practice, 226.

Chakraborty, S., Sarker, S., \& Sarker, S. (2010). An exploration into the process of requirements elicitation: A grounded approach. Journal of the Association for Information Systems, 11(4), 212.

Chang, J., Levy, M., \& Powell, P. (2009). Process re-engineering success in small and medium sized enterprises. Enterprise Information Systems for Business Integration in SMEs: Technological, Organizational, and Social Dimensions: Technological, Organizational, and Social Dimensions, 363.

Davenport, T. H. (1993). Process innovation: reengineering work through information technology: Harvard Business Press, 1993. 
Fan, B., \& Zhao, Y. (2017). The moderating effect of external pressure on the relationship between internal organizational factors and the quality of open government data. Government Information Quarterly, 34(3), 396-405.

Goedertier, S., \& Vanthienen, J. (2006). Compliant and flexible business processes with business rules. Paper presented at the 7th Workshop on Business Process Modeling, Development and Support (BPMDS'06) at CAiSE'06.

Gong, Y., \& Janssen, M. (2012). From policy implementation to business process management: Principles for creating flexibility and agility. Government Information Quarterly, 29(suppl. 1), S61-S71.

Grgecic, D. (2011). Applying structuration theory to investigate business process change. Paper presented at the System Sciences (HICSS), 2011 44th Hawaii International Conference on.

Grover, V., \& Kettinger, W. J. (2000). Process think: winning perspectives for business change in the information age: IGI Global, 2000.

Grover, V., \& Otim, S. (2009). A Framework for Business Process Change Requirements Analysis. In Design Requirements Engineering: A Ten-Year Perspective (pp. 327-351): Springer, 2009.

Habjan, A., Popovic, A., \& ENGLAND, S. (2008). How internal processes benefit from IT investments and therefore enhance company's competitiveness-a case study of Slovenian small and medium sized companies. WSEAS Transactions on Business and Economics, 5(5), 233-242.

Hansen, K., Gann, D., \& Groak, S. (1998). Information technology decision support and business process change in the USA. Engineering, Construction and Architectural Management, 5(2), 115-126.

Harmon, P. (2010). The scope and evolution of business process management. In In Handbook on Business Process Management 1 (pp. 37-81). Berlin Heidelberg: Springer.

Harmon, P. (2014). Business process change (Third ed.): Morgan Kaufmann, 2014.

Heeks, R. (2003). Most egovernment-for-development projects fail: how can risks be reduced? (Vol. 14): Institute for Development Policy and Management, University of Manchester Manchester.

Hiatt, J. M., \& Creasey, T. J. (2012). Change Management: The People Side of Change: Prosci Learning Center Publications, 2012.

Huizing, A., Koster, E., \& Bouman, W. (1997). Balance in business reengineering: an empirical study of fit and performance. Journal of Management Information Systems, 14(1), 93-118.

ITU. (2011). THE ROLE OF ICT IN ADVANCING GROWTH IN LEAST DEVELOPED COUNTRIES: TRENDS, CHALLENGES AND OPPORTUNITIES. Retrieved from Geneva: http://www.itu.int/pub/D-LDCICTLDC.2011-2011 Accessed (17 April 2016).

Jurisch, M. (2014). IT-enabled Business Process Change in Private and in Public Sector Organizations. München, Technische Universität München, Diss., 2014,

Jurisch, M., Cuno, J., Palka, W., Wolf, P., \& Krcmar, H. (2012). An integrative model of IT-enabled business process change: causal structures in theory, research and practice. Paper presented at the System Science (HICSS), 2012 45th Hawaii International Conference on.

Jurisch, M., Ikas, C., Wolf, P., \& Krcmar, H. (2013). Key Differences of Private and Public Sector Business Process Change. e-Service Journal, 9(1), 3-27.

Jurisch, M., Palka, W., Wolf, P., \& Krcmar, H. (2014). Which capabilities matter for successful business process change? Business Process Management Journal, 20(1), 47-67.

Jurisch, M., Rosenberg, Z., \& Krcmar, H. (2016). Emergent risks in business process change projects. Business Process Management Journal, 22(4), 791-811.

Kaplan, R. B., Murdock, L., \& Ostroff, F. (1991). Core process redesign. The McKinsey Quarterly, (2), 27.

Kavakli, V., \& Loucopoulos, P. (1999). Goal-driven business process analysis application in electricity deregulation. Information Systems, 24(3), 187-207.

Kettinger, W. J., \& Grover, V. (1995). Special section: toward a theory of business process change management. Journal of Management Information Systems, 12(1), 9-30. 
Kettinger, W. J., \& Teng, J. T. (1998). Aligning BPR to strategy: a framework for analysis. Long Range Planning, 31(1), 93-107.

Kettinger, W. J., Teng, J. T. C., \& Guha, S. (1997). Business process change: a study of methodologies, techniques, and tools. Mis Quarterly, 21(1), 55-80.

Kirchmer, M. (2015). Management of process excellence. In In Handbook on Business Process Management 2 (pp. 79-99). Berlin Heidelberg: Springer.

Langer, A. M. (2017). Information Technology and Organizational Learning: Managing Behavioral Change in the Digital Age (3rd ed.). Milton: CRC Press, 2017.

Lee, Y. W., Strong, D. M., Kahn, B. K., \& Wang, R. Y. (2002). AIMQ: a methodology for information quality assessment. Information \& management, 40(2), 133-146.

Luftman, J. (2015). Strategic alignment maturity. In In Handbook on Business Process Management 2 (pp. 5-43). Berlin Heidelberg: Springer.

Luna-Reyes, L. F., \& Andersen, D. L. (2003). Collecting and analyzing qualitative data for system dynamics: methods and models. System Dynamics Review, 19(4), 271-296.

Luo, W., \& Alex Tung, Y. (1999). A framework for selecting business process modeling methods. Industrial Management \& Data Systems, 99(7), 312-319.

Magutu, P. (2010). Business Process Reengineering for Competitive Advantage: Key Factors that may lead to the success or failure of the BPR implementation. African Journal of Business \& Management, 1(1), 16.

Malhotra, Y. (1998). Business process redesign: an overview. IEEE Engineering Management Review, 26(3), 27-31.

Malihi, E., \& Aghdasi, M. (2014). A decision framework for optimisation of business processes aligned with business goals. International Journal of Business Information Systems, 15(1), 22-42.

Martinsons, M. G., \& Davison, R. M. (2007). Culture's consequences for IT application and business process change: a research agenda. International Journal of Internet and Enterprise Management, 5(2), 158-177.

Matheson, J. (2005). Decision analysis= decision engineering. In J. C. Smith \& H. J. Greenberg (Eds.), 2005 Tutorials in Operations Research: Emerging Theory, Methods, and Applications (pp. 195212): INFORMS, 2005.

McNamee, P., \& Celona, J. (2005). Decision analysis for the professional: SmartOrg, Incorporated.

Nair, M., Kuppusamy, M., \& Davison, R. (2005). A Longitudinal Study on the Global Digital Divide Problem: Strategies to Close Cross-Country Digital Gap. The Business Review, Cambridge, 4(1), 315-326.

Neumann, J. (2014). A framework for monitoring and evaluating critical success factors in strategic change programme implementation: a case study of a global industrial company in the energy sector. Northumbria University,

Niehaves, B., Plattfaut, R., \& Becker, J. (2013). Business process management capabilities in local governments: A multi-method study. Government Information Quarterly, 30(3), 217-225.

Pateli, A., \& Philippidou, S. (2011). Applying business process change (BPC) to implement multi-agency collaboration: the case of the Greek public administration. Journal of theoretical and applied electronic commerce research, 6(1), 127-142.

Paul, D., Yeates, D., \& Cadle, J. (2014). Business analysis (3rd ed.): BCS, The Chartered Institute for IT, 2014.

Ploesser, K., Recker, J., \& Rosemann, M. (2008). Towards a Classification and Lifecycle of Business Process Change. Proceedings of BPMDS, 8, 11.

Prattipati, S. N. (2003). Adoption of e-governance: differences between countries in the use of online government services. Journal of American Academy of Business, 3(1/2), 386-391.

Rausch, E., \& Anderson, C. (2011). Enhancing decisions with criteria for quality. Management Decision, 49(5), 722-733. doi:10.1108/00251741111130814

Reijers, H. A., \& Mansar, S. L. (2005). Best practices in business process redesign: an overview and qualitative evaluation of successful redesign heuristics. Omega, 33(4), 283-306. 
Rinderle, S., Reichert, M., \& Dadam, P. (2004). Correctness criteria for dynamic changes in workflow systems-a survey. Data \& Knowledge Engineering, 50(1), 9-34.

Rosenberg, Z., Jurisch, M., Schermann, M., \& Krcmar, H. (2014). Using Case Survey Methodology to Extract Variables and Causal Links: An Example from Studying Business Process Change. Paper presented at the Proceedings of the 32nd International Conference of the System Dynamics Society, Wiley, Delft, Netherlands.

Scholl, H. J. (2003). E-government: a special case of ICT-enabled business process change. Paper presented at the Proceedings of the 36th Annual Hawaii International Conference on System Sciences, IEEE.

Sikdar, A., \& Payyazhi, J. (2014). A process model of managing organizational change during business process redesign. Business Process Management Journal, 20(6), 971-998.

Škerlavaj, M., Štemberger, M. I., \& Dimovski, V. (2007). Organizational learning culture-the missing link between business process change and organizational performance. International Journal of Production Economics, 106(2), 346-367.

Soffer, P. (2004). Analyzing the Scope of a Change in a Business Process Model. Paper presented at the Proc. of Int'I Conference on Advanced Information Systems Engineering Workshops.

Soffer, P. (2005). Scope analysis: identifying the impact of changes in business process models. Software Process: Improvement and Practice, 10(4), 393-402.

Stemberger, M., \& Jaklic, J. (2007). Towards E-government by business process change-A methodology for public sector. International Journal of Information Management, 27(4), 221232.

Stufflebeam, D. (2001). Evaluation models. New directions for evaluation, 2001(89), 7-98.

Thomas, A. (2008). Business Process Change. published in Student Accountant.

Vakola, M., \& Rezgui, Y. (2000). Critique of existing business process re-engineering methodologies: The development and implementation of a new methodology. Business Process Management Journal, 6(3), 238-250.

Wang, C., Medaglia, R., \& Zheng, L. (2017). Towards a typology of adaptive governance in the digital government context: The role of decision-making and accountability. Government Information Quarterly.

Whelan-Berry, K. S., \& Somerville, K. A. (2010). Linking change drivers and the organizational change process: A review and synthesis. Journal of Change Management, 10(2), 175-193.

Wu, S. P.-J., Straub, D. W., \& Liang, T.-P. (2015). How information technology governance mechanisms and strategic alignment influence organizational performance: Insights from a matched survey of business and it managers. Mis Quarterly, 39(2), 497-518.

Zellner, G. (2011). A structured evaluation of business process improvement approaches. Business Process Management Journal, 17(2), 203-237. doi:10.1108/14637151111122329

Zellner, G. (2013). Towards a framework for identifying business process redesign patterns. Business Process Management Journal, 19(4), 600-623.

Zigiaris, S. (2000). Business Process Re-engineering BPR. Report produced for the EC funded project-INNOREGIO: dissemination of innovation and knowledge management techniques. 


\section{Appendices}

\subsection{Tables}

6.1.1. Table 4: List of Hafiz's Organisational Functions and Roles

\begin{tabular}{|c|c|c|c|c|}
\hline Abbr. & Role & Description & Responsibility & Context \\
\hline HPM & $\begin{array}{l}\text { Hafiz Program } \\
\text { Manager }\end{array}$ & Manage all program issues and & $\begin{array}{l}\text { Acts chief executive officer } \\
\text { for Hafiz Program }\end{array}$ & Management \\
\hline $\mathrm{CBO}$ & $\begin{array}{l}\text { Chief Business } \\
\text { Officer }\end{array}$ & $\begin{array}{l}\text { Managing all business and } \\
\text { administration functions }\end{array}$ & $\begin{array}{l}\text { is responsible for the } \\
\text { administrative, financial } \\
\text { management of the } \\
\text { organisation }\end{array}$ & $\begin{array}{l}\text { Administration } \\
\text { and financial }\end{array}$ \\
\hline $\mathrm{COO}$ & $\begin{array}{l}\text { Chief } \\
\text { Operation } \\
\text { Officer }\end{array}$ & Handling operation functions & $\begin{array}{l}\text { Responsible Day to day for } \\
\text { development, design, } \\
\text { operation, and improvement } \\
\text { of the systems }\end{array}$ & Operation \\
\hline СТO & $\begin{array}{l}\text { Chief } \\
\text { Technology } \\
\text { Officer }\end{array}$ & $\begin{array}{l}\text { An executive position whose manage } \\
\text { and address technical issues that a } \\
\text { company faces }\end{array}$ & $\begin{array}{l}\text { Responsible is to manage and } \\
\text { address all technical issues in }\end{array}$ & $\begin{array}{l}\text { Information } \\
\text { Technology }\end{array}$ \\
\hline SBA & $\begin{array}{l}\text { Senior } \\
\text { Business } \\
\text { Architecture }\end{array}$ & $\begin{array}{l}\text { Provides business architecture, } \\
\text { change/transition management, } \\
\text { consultation, facilitation, senior } \\
\text { analysis, and project management }\end{array}$ & $\begin{array}{l}\text { Responsible of all business } \\
\text { architect aspects that the } \\
\text { entity has }\end{array}$ & IT, Management \\
\hline BPMO & $\begin{array}{l}\text { Business } \\
\text { Process Officer }\end{array}$ & $\begin{array}{l}\text { Manage and monitor business process } \\
\text { activities }\end{array}$ & $\begin{array}{l}\text { In charge of all business } \\
\text { process actions and } \\
\text { monitoring }\end{array}$ & Management \\
\hline SOM & $\begin{array}{l}\text { Senior } \\
\text { Operation } \\
\text { Manager }\end{array}$ & $\begin{array}{l}\text { Cover and manage all operation } \\
\text { aspects }\end{array}$ & $\begin{array}{l}\text { Supervise all operation } \\
\text { activities }\end{array}$ & IT \\
\hline QAO & $\begin{array}{l}\text { Quality } \\
\text { Assurance } \\
\text { Officer }\end{array}$ & $\begin{array}{l}\text { Supervise the quality of the whole } \\
\text { processes. }\end{array}$ & $\begin{array}{l}\text { creates, implements and } \\
\text { manages business quality } \\
\text { control system }\end{array}$ & Management \\
\hline CEA & $\begin{array}{l}\text { Chief } \\
\text { Enterprise } \\
\text { Architect }\end{array}$ & $\begin{array}{l}\text { arrange strategy, processes and IT } \\
\text { assets }\end{array}$ & $\begin{array}{l}\text { Aligns all functions and } \\
\text { processes }\end{array}$ & Management, IT \\
\hline STM & $\begin{array}{l}\text { Senior } \\
\text { Technology } \\
\text { Manager }\end{array}$ & Supervise IT aspects & $\begin{array}{l}\text { Responsible for the related IT } \\
\text { duties }\end{array}$ & IT \\
\hline
\end{tabular}


6.1.2. Table 5: List of Hafiz's Business Processes Mapped with its Objectives, Functional and Importance

\begin{tabular}{|c|c|c|c|c|c|}
\hline Abbr. & Business Process & Description & Objective & $\begin{array}{l}\text { Functional } \\
\text { ownership }\end{array}$ & $\begin{array}{c}\text { Importance } \\
\text { (1=Low- } \\
5=\text { High })\end{array}$ \\
\hline CRP & $\begin{array}{l}\text { Candidate } \\
\text { Registration Process }\end{array}$ & $\begin{array}{l}\text { This BP is responsible for the initial } \\
\text { registration of Hafiz beneficiaries. }\end{array}$ & RUP & $\begin{array}{l}\text { Application } \\
\text { Processing }\end{array}$ & 4 \\
\hline CEP & $\begin{array}{l}\text { Candidate } \\
\text { Evaluation Process }\end{array}$ & $\begin{array}{l}\text { To evaluate the eligibility of the } \\
\text { applicant }\end{array}$ & RUP & $\begin{array}{l}\text { Application } \\
\text { Processing }\end{array}$ & 5 \\
\hline CAP & $\begin{array}{l}\text { Candidate Approval } \\
\text { Process }\end{array}$ & $\begin{array}{l}\text { The full approval process to approve } \\
\text { candidate }\end{array}$ & RUP & $\begin{array}{l}\text { Application } \\
\text { Processing }\end{array}$ & 5 \\
\hline GOSIP & $\begin{array}{l}\text { GOSI Coordination } \\
\text { Process }\end{array}$ & $\begin{array}{l}\text { General Organisation for Social } \\
\text { Insurance integration }\end{array}$ & RUP & Coordination & 5 \\
\hline MLP & $\begin{array}{l}\text { MOL Coordination } \\
\text { Process }\end{array}$ & Ministry of Labour integration & RUP & Coordination & 5 \\
\hline MIP & $\begin{array}{l}\text { MOI coordination } \\
\text { Process }\end{array}$ & Ministry of Interior integration & RUP & Coordination & 5 \\
\hline MCIP & $\begin{array}{l}\text { MCI Coordination } \\
\text { Process }\end{array}$ & $\begin{array}{l}\text { Ministry of Commerce and Industry } \\
\text { integration }\end{array}$ & RUP & Coordination & 5 \\
\hline MFP & $\begin{array}{l}\text { MOF Coordination } \\
\text { Process }\end{array}$ & Ministry of Finance integration & RUP & Coordination & 5 \\
\hline MHEP & $\begin{array}{l}\text { MOHE } \\
\text { Coordination } \\
\text { Process }\end{array}$ & $\begin{array}{l}\text { Ministry of Higher Education } \\
\text { Integration }\end{array}$ & RUP & Coordination & 3 \\
\hline BTP & $\begin{array}{l}\text { Beneficiary } \\
\text { Training Process }\end{array}$ & The entire training process & TMBD & Training & 4 \\
\hline $\mathrm{MCP}$ & $\begin{array}{l}\text { Monitoring and } \\
\text { Controlling Process }\end{array}$ & $\begin{array}{l}\text { The entire process to check all the } \\
\text { activities }\end{array}$ & RUP & Control & 5 \\
\hline SGAP & $\begin{array}{l}\text { Skill Gap Analysis } \\
\text { Process }\end{array}$ & $\begin{array}{l}\text { The rate of how many beneficiaries } \\
\text { acquired job chance }\end{array}$ & RUP & Data Analysis & 5 \\
\hline BPP & $\begin{array}{l}\text { Beneficiary } \\
\text { Payment Processing }\end{array}$ & The process of delivering the payments & FI & Payment & 5 \\
\hline DPP & $\begin{array}{l}\text { Deduction \& } \\
\text { Penalty Processing }\end{array}$ & The legitimacy process & FI & Payment & 4 \\
\hline CMP & $\begin{array}{l}\text { Complaints } \\
\text { Management } \\
\text { Process }\end{array}$ & The process of controlling complaints & RUP & Control & 4 \\
\hline DRP & $\begin{array}{l}\text { Dispute Resolution } \\
\text { Process }\end{array}$ & The process of controlling disputes & RUP & Control & 4 \\
\hline RMP & $\begin{array}{l}\text { Report Management } \\
\text { Process }\end{array}$ & The process of managing reports & RUP & Report & 4 \\
\hline $\mathrm{OCP}$ & $\begin{array}{l}\text { Organisation } \\
\text { Coordination } \\
\text { Process }\end{array}$ & The process of coordination & RUP & Coordination & 5 \\
\hline JMP & $\begin{array}{l}\text { Job Matching } \\
\text { Processing }\end{array}$ & The process of matching job & $\begin{array}{l}\text { RUP, } \\
\text { HJSE }\end{array}$ & Control & 4 \\
\hline ESR & $\begin{array}{l}\text { Enhance student's } \\
\text { ineligibility reason }\end{array}$ & $\begin{array}{l}\text { Improving the ineligibility reason for } \\
\text { students to specify which university } \\
\text { they are still recorded in }\end{array}$ & $\begin{array}{l}\text { RUP, } \\
\text { HJSE }\end{array}$ & Control & 4 \\
\hline
\end{tabular}


6.1.3. Table 6: Hafiz's Business Processes and Risks Mapping Matrix

\begin{tabular}{|c|c|c|c|c|c|c|c|c|}
\hline $\begin{array}{c}\text { Risk } \\
\text { Business Process }\end{array}$ & $\begin{array}{c}\text { System } \\
\text { unavailability }\end{array}$ & $\begin{array}{l}\text { Erroneous } \\
\text { candidate } \\
\text { evaluation }\end{array}$ & $\begin{array}{l}\text { Negative } \\
\text { ripple } \\
\text { effect }\end{array}$ & $\begin{array}{c}\text { Inability to } \\
\text { achieve change } \\
\text { objectives }\end{array}$ & $\begin{array}{l}\text { Quality of } \\
\text { data received } \\
\text { from agencies }\end{array}$ & $\begin{array}{c}\text { Delay in } \\
\text { receiving } \\
\text { data }\end{array}$ & $\begin{array}{c}\text { Financial } \\
\text { funding }\end{array}$ & $\begin{array}{c}\text { Technical } \\
\text { Issues }\end{array}$ \\
\hline $\begin{array}{l}\text { Candidate } \\
\text { Registration } \\
\text { Process }\end{array}$ & 1 & 2 & 2 & 3 & 0 & 0 & 0 & 2 \\
\hline $\begin{array}{l}\text { Candidate } \\
\text { Evaluation } \\
\text { Process }\end{array}$ & 1 & 2 & 2 & 3 & 2 & 2 & 0 & 3 \\
\hline $\begin{array}{l}\text { Candidate } \\
\text { Approval Process }\end{array}$ & 1 & 2 & 2 & 3 & 2 & 2 & 4 & 3 \\
\hline $\begin{array}{l}\text { GOSI } \\
\text { Coordination } \\
\text { Process }\end{array}$ & 1 & 0 & 3 & 2 & 1 & 1 & 0 & 3 \\
\hline $\begin{array}{l}\text { MOL } \\
\text { Coordination } \\
\text { Process }\end{array}$ & 1 & 0 & 3 & 2 & 1 & 1 & 0 & 3 \\
\hline $\begin{array}{l}\text { MOI } \\
\text { coordination } \\
\text { Process }\end{array}$ & 1 & 0 & 3 & 2 & 1 & 1 & 0 & 3 \\
\hline $\begin{array}{l}\text { MCI } \\
\text { Coordination } \\
\text { Process }\end{array}$ & 1 & 0 & 3 & 2 & 1 & 1 & 0 & 3 \\
\hline $\begin{array}{l}\text { MOF } \\
\text { Coordination } \\
\text { Process }\end{array}$ & 1 & 0 & 3 & 2 & 1 & 1 & 0 & 3 \\
\hline $\begin{array}{l}\text { MOHE } \\
\text { Coordination } \\
\text { Process }\end{array}$ & 1 & 0 & 3 & 2 & 1 & 1 & 0 & 3 \\
\hline $\begin{array}{l}\text { Beneficiary } \\
\text { Training Process }\end{array}$ & 0 & 0 & 4 & 2 & 0 & 0 & 4 & 0 \\
\hline $\begin{array}{l}\text { Monitoring and } \\
\text { Controlling } \\
\text { Process }\end{array}$ & 2 & 2 & 2 & 2 & 3 & 1 & 0 & 2 \\
\hline $\begin{array}{l}\text { Skill Gap } \\
\text { Analysis Process }\end{array}$ & 2 & 0 & 3 & 1 & 4 & 3 & 0 & 4 \\
\hline
\end{tabular}




\begin{tabular}{|c|c|c|c|c|c|c|c|c|}
\hline $\begin{array}{c}\text { Risk } \\
\text { Business Process }\end{array}$ & $\begin{array}{c}\text { System } \\
\text { unavailability }\end{array}$ & $\begin{array}{l}\text { Erroneous } \\
\text { candidate } \\
\text { evaluation }\end{array}$ & $\begin{array}{l}\text { Negative } \\
\text { ripple } \\
\text { effect }\end{array}$ & $\begin{array}{l}\text { Inability to } \\
\text { achieve change } \\
\text { objectives }\end{array}$ & $\begin{array}{c}\text { Quality of } \\
\text { data received } \\
\text { from agencies }\end{array}$ & $\begin{array}{l}\text { Delay in } \\
\text { receiving } \\
\text { data }\end{array}$ & $\begin{array}{l}\text { Financial } \\
\text { funding }\end{array}$ & $\begin{array}{l}\text { Technical } \\
\text { Issues }\end{array}$ \\
\hline $\begin{array}{l}\text { Beneficiary } \\
\text { Payment } \\
\text { Processing }\end{array}$ & 3 & 0 & 2 & 2 & & 2 & 1 & 2 \\
\hline $\begin{array}{l}\text { Deduction \& } \\
\text { Penalty } \\
\text { Processing }\end{array}$ & 3 & 0 & 4 & 3 & 2 & 3 & 3 & 3 \\
\hline $\begin{array}{l}\text { Complaints } \\
\text { Management } \\
\text { Process }\end{array}$ & 0 & 3 & 3 & 4 & 2 & 3 & 3 & 3 \\
\hline $\begin{array}{l}\text { Dispute } \\
\text { Resolution } \\
\text { Process }\end{array}$ & 5 & 3 & 3 & 4 & 2 & 0 & 0 & 4 \\
\hline $\begin{array}{l}\text { Report } \\
\text { Management } \\
\text { Process }\end{array}$ & 3 & 5 & 3 & 4 & 0 & 0 & 0 & 5 \\
\hline $\begin{array}{l}\text { Organisation } \\
\text { Coordination } \\
\text { Process }\end{array}$ & 1 & 0 & 1 & 1 & 0 & 0 & 0 & 1 \\
\hline $\begin{array}{l}\text { Job Matching } \\
\text { Processing }\end{array}$ & 4 & 2 & 2 & 1 & 3 & 4 & 5 & 4 \\
\hline $\begin{array}{l}\text { Enhance } \\
\text { students' } \\
\text { ineligibility } \\
\text { reason }\end{array}$ & 2 & 3 & 4 & 1 & 3 & 2 & 5 & 4 \\
\hline
\end{tabular}


6.1.4. Table 7: Hafiz's Business Process and Key Performance Indicators Mapping Matrix

\begin{tabular}{|c|c|c|c|c|c|c|c|c|c|}
\hline $\begin{array}{l}\text { Performance } \\
\quad \text { Indicator } \\
\text { Business } \\
\text { Process }\end{array}$ & $\begin{array}{c}\text { Registration } \\
\text { Quality }\end{array}$ & $\begin{array}{l}\text { Decision } \\
\text { Quality }\end{array}$ & $\begin{array}{l}\text { Training } \\
\text { Quality }\end{array}$ & $\begin{array}{c}\text { Average } \\
\text { Complaint } \\
\text { Resolution } \\
\text { Rate }\end{array}$ & $\begin{array}{l}\text { Technical } \\
\text { Issues } \\
\text { Resolution } \\
\text { Rate }\end{array}$ & $\begin{array}{c}\text { Employment } \\
\text { Rate due to } \\
\text { Hafiz }\end{array}$ & $\begin{array}{l}\text { Number } \\
\text { of } \\
\text { Tickets }\end{array}$ & $\begin{array}{l}\text { Number of } \\
\text { endorsed } \\
\text { Appeals }\end{array}$ & $\begin{array}{l}\text { Number of } \\
\text { Rejected } \\
\text { Payments }\end{array}$ \\
\hline $\begin{array}{l}\text { Candidate } \\
\text { Registration } \\
\text { Process }\end{array}$ & 1 & 0 & 0 & 4 & 3 & 4 & 4 & 3 & 0 \\
\hline $\begin{array}{l}\text { Candidate } \\
\text { Approval } \\
\text { Process }\end{array}$ & 2 & 1 & 0 & 5 & 4 & 2 & 3 & 3 & 0 \\
\hline $\begin{array}{l}\text { GOSI } \\
\text { Coordination } \\
\text { Process }\end{array}$ & 1 & 2 & 0 & 5 & 3 & 3 & 6 & 0 & 0 \\
\hline $\begin{array}{l}\text { MOI } \\
\text { coordination } \\
\text { Process }\end{array}$ & 1 & 2 & 0 & 5 & 3 & 3 & 6 & 0 & 0 \\
\hline $\begin{array}{l}\text { MCI } \\
\text { Coordination } \\
\text { Process }\end{array}$ & 1 & 2 & 0 & 5 & 3 & 3 & 6 & 0 & 0 \\
\hline $\begin{array}{l}\text { MOF } \\
\text { Coordination } \\
\text { Process }\end{array}$ & 1 & 2 & 0 & 5 & 3 & 3 & 6 & 0 & 0 \\
\hline $\begin{array}{l}\text { MOHE } \\
\text { Coordination } \\
\text { Process }\end{array}$ & 1 & 2 & 0 & 5 & 3 & 3 & 6 & 0 & 0 \\
\hline
\end{tabular}




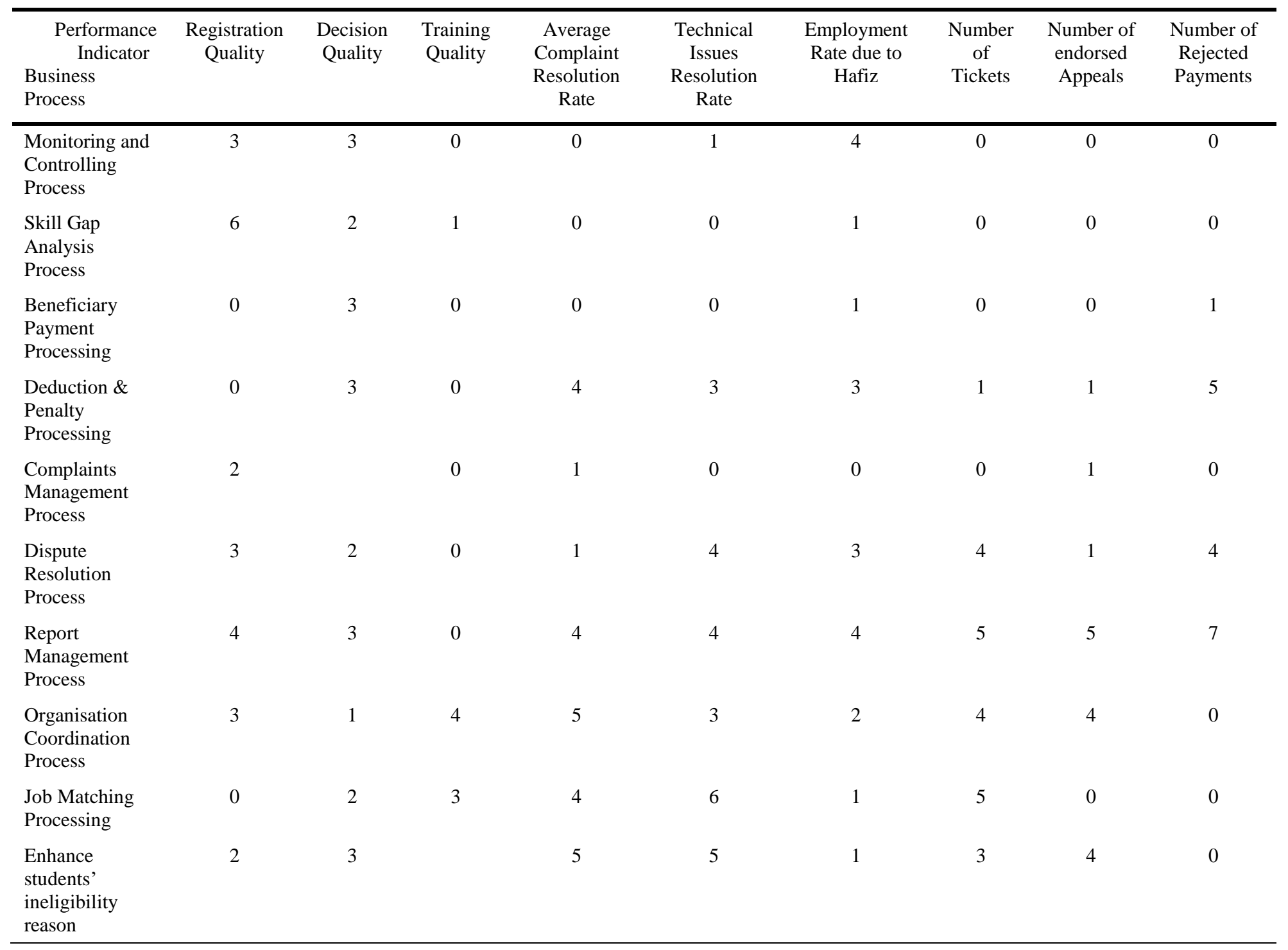


6.1.5. Table 8: List of Hafiz's Application Information

\begin{tabular}{clll}
\hline App. Abbreviation & Application name & Description & Ownership \\
\hline CAPS & $\begin{array}{l}\text { Candidate Application Processing } \\
\text { System }\end{array}$ & Process applications system & $\begin{array}{l}\text { Application } \\
\text { processing }\end{array}$ \\
TMS & Training Management System & Provide training & Training \\
PPS & Payment Processing System & Process payment & $\begin{array}{l}\text { Payment } \\
\text { processing }\end{array}$ \\
CIP & Coordination \& Integration Platform & Link Hafiz Program with the & Coordination \\
RDP & Report \& Data Analysis Platform & Maintain reporting and analysis & Reporting \\
MCS & Monitoring \& Control System & Monitoring system & Control \\
HMP & Hafiz Main Portal & Host applications & Data analysis \\
\hline
\end{tabular}

6.1.6. Table 9: Hafiz's Application and Functional Ownership Mapping Matrix

\begin{tabular}{lccccccc}
\hline \multicolumn{1}{c}{ Application Name } & CAPS & TMS & PPS & CIP & RDP & MCS & HMP \\
Functional Structure & & & & & & & \\
\hline Application Processing & 1 & 6 & 4 & 3 & 5 & 4 & 6 \\
Data Analysis & 2 & 4 & 6 & 5 & 4 & 3 & 7 \\
Control & 1 & 5 & 2 & 2 & 2 & 4 & 4 \\
Training & 6 & 1 & 7 & 0 & 5 & 3 & 3 \\
Coordination & 2 & 6 & 3 & 1 & 4 & 3 & 5 \\
Payment Processing & 4 & 0 & 1 & 2 & 3 & 3 & 5 \\
Reporting & 3 & 1 & 4 & 5 & 1 & 3 & 3 \\
\hline
\end{tabular}

6.1.7. Table 10: Hafiz's Application and Business Process Mapping Matrix

\begin{tabular}{|c|c|c|c|c|c|c|c|}
\hline $\begin{array}{ll} & \text { Application } \\
\text { Business Process } & \end{array}$ & CAPS & TMS & PPS & CIP & RDP & MCS & HMP \\
\hline Candidate Registration Process & 3 & 0 & 0 & 0 & 7 & 7 & 4 \\
\hline Candidate Evaluation Process & 4 & 0 & 0 & 1 & 7 & 7 & 5 \\
\hline Candidate Approval Process & 1 & 0 & 7 & 3 & 4 & 6 & 3 \\
\hline GOSI Coordination Process & 4 & 0 & 0 & 1 & 4 & 3 & 0 \\
\hline MOL Coordination Process & 4 & 0 & 0 & 1 & 4 & 3 & 0 \\
\hline MOI coordination Process & 4 & 0 & 0 & 1 & 4 & 3 & 0 \\
\hline MCI Coordination Process & 4 & 0 & 0 & 1 & 4 & 3 & 0 \\
\hline MOF Coordination Process & 4 & 0 & 0 & 1 & 4 & 3 & 0 \\
\hline MOHE Coordination Process & 4 & 0 & 0 & 1 & 4 & 3 & 0 \\
\hline Beneficiary Training Process & 0 & 1 & 0 & 5 & 3 & 2 & 6 \\
\hline $\begin{array}{l}\text { Monitoring and Controlling } \\
\text { Process }\end{array}$ & 2 & 3 & 6 & 1 & 3 & 1 & 6 \\
\hline
\end{tabular}




\begin{tabular}{lccccccc}
\hline \multicolumn{1}{c}{ Application } & CAPS & TMS & PPS & CIP & RDP & MCS & HMP \\
Business Process & & & & & & & \\
\hline Skill Gap Analysis Process & 2 & 2 & 0 & 5 & 5 & 5 & 0 \\
Beneficiary Payment Processing & 4 & 0 & 1 & 5 & 4 & 4 & 0 \\
Deduction \& Penalty Processing & 5 & 0 & 1 & 2 & 3 & 3 & 0 \\
Complaints Management Process & 1 & 2 & 1 & 1 & 3 & 4 & 3 \\
Dispute Resolution Process & 5 & 4 & 2 & 4 & 3 & 4 & 4 \\
Report Management Process & 4 & 5 & 4 & 4 & 3 & 4 & 5 \\
Organisation Coordination Process & 2 & 8 & 4 & 1 & 4 & 4 & 3 \\
Job Matching Processing & 4 & 1 & 0 & 3 & 3 & 3 & 4 \\
Enhance students' ineligibility & 3 & 0 & 2 & 3 & 3 & 2 & 0 \\
reason & & & & & & & \\
\hline
\end{tabular}

6.1.8. Table 11: List of Hafiz's Organisational Change Management Drivers

\begin{tabular}{|c|c|c|}
\hline Drivers & Description & Entity \\
\hline $\begin{array}{l}\text { New government policy for } \\
\text { unemployment }\end{array}$ & $\begin{array}{l}\text { Orders from the King or the Cabinet to } \\
\text { change or solve the unemployment }\end{array}$ & Saudi Government \\
\hline $\begin{array}{l}\text { Economic policy (Human } \\
\text { Capital) }\end{array}$ & $\begin{array}{l}\text { Any update or change policies that } \\
\text { imposed from the Cabinet }\end{array}$ & $\begin{array}{l}\text { Ministry of Finance, Ministry of Economic } \\
\text { and Planning }\end{array}$ \\
\hline $\begin{array}{l}\text { Complaints against the } \\
\text { program }\end{array}$ & $\begin{array}{l}\text { Criticisms or complaints from the public } \\
\text { or the beneficiaries }\end{array}$ & Ministry of Labour \\
\hline Proactive improvement & The continuation to improve the services & Hafiz Program \\
\hline Political issues & The act to achieve public aspirations & Saudi Government \\
\hline Social and cultural issues & $\begin{array}{l}\text { The act to solve common public and } \\
\text { culture issues }\end{array}$ & Saudi Government and Citizens \\
\hline $\begin{array}{l}\text { Increase in unemployment } \\
\text { rate }\end{array}$ & $\begin{array}{l}\text { That due to decrease of job opportunities } \\
\text { or GPI etc... }\end{array}$ & Saudi Government, Ministry of Labour \\
\hline $\begin{array}{l}\text { Coordination with other } \\
\text { entities }\end{array}$ & To exchange citizen's information & $\begin{array}{l}\text { General Organisation for Social Insurance, } \\
\text { Ministry of Labour, Ministry of Interior, ... }\end{array}$ \\
\hline $\begin{array}{l}\text { Growth in users and } \\
\text { services in Hafiz Program }\end{array}$ & The increase of unemployment rate & Hafiz Program \\
\hline Quality of Services & $\begin{array}{l}\text { The advancement to deliver good service } \\
\text { that satisfy the customers }\end{array}$ & Ministry of Labour \\
\hline $\begin{array}{l}\text { Change in executives or } \\
\text { management }\end{array}$ & $\begin{array}{l}\text { The change of positions or strategies due } \\
\text { to new management }\end{array}$ & Ministry of Labour, Hafiz Program \\
\hline $\begin{array}{l}\text { Change in technology and } \\
\text { infrastructures }\end{array}$ & $\begin{array}{l}\text { The demand to upgrade or enhance of } \\
\text { new technology to continue the service }\end{array}$ & Technology trends and vendors \\
\hline
\end{tabular}


6.1.9. Table 12: Hafiz's Organisational Change Management Drivers Impact Mapping Matrix

\begin{tabular}{lll}
\hline Drivers & Objective & Business Process \\
\hline Government policy & Solve unemployment rate through intensive fund & $\begin{array}{l}\text { Registration Process } \\
\text { Approval Process } \\
\text { Payment Processing }\end{array}$ \\
Economic policy & Decrease fund due to decline income & Payment Processing \\
Complaints & Solve complaints & Monitoring and Controlling Process \\
Improvement & Improve service & Complaints Management Process \\
Political issues & Decrease unemployment rate & Improvement process \\
Growth in unemployment & Offer jobs and opportunities & $\begin{array}{l}\text { Beneficiary Training Process } \\
\text { Skill Gap Analysis Process }\end{array}$ \\
Coordination & Improve data quality & Beneficiary Training Process \\
Service and users' growth & Improve services to accommodate the growth of users & Improvement process \\
Quality of services & Satisfy users & Improvement process \\
Management change & Improve services & Monitoring and Controlling Process \\
Technology Dynamics & Improve services & Improvement process \\
\hline
\end{tabular}


6.1.10. Table 13: Linking of Hafiz's Organisational Change Management Drivers with Business Process Scenarios

\begin{tabular}{|c|c|c|c|}
\hline \multirow{2}{*}{$\#$} & \multirow{2}{*}{$\begin{array}{l}\text { Drivers } \\
\text { Government policy }\end{array}$} & \multicolumn{2}{|c|}{ Scenarios } \\
\hline & & $\begin{array}{l}1.1 . \\
1.2 . \\
1.3 .\end{array}$ & $\begin{array}{l}\text { Cutting budget from Hafiz Program } \\
\text { Increase the period of benefits } \\
\text { Increase or decrease beneficiaries age range }\end{array}$ \\
\hline 2. & Economic policy & $\begin{array}{l}1.4 . \\
1.5 . \\
1.6 .\end{array}$ & $\begin{array}{l}\text { Decrease government income } \\
\text { Increase inflation rate } \\
\text { Increase wages }\end{array}$ \\
\hline 3. & Complaints & $\begin{array}{l}1.7 . \\
1.8 . \\
1.9 \\
1.10\end{array}$ & $\begin{array}{l}\text { Change management and executives } \\
\text { Upgrade program } \\
\text { Use outsourcing } \\
\text { Increase cost of operation }\end{array}$ \\
\hline 4. & Improvement & $\begin{array}{l}1.11 . \\
1.12 . \\
1.13 .\end{array}$ & $\begin{array}{l}\text { Add new software and programs } \\
\text { Change and improve policies } \\
\text { Add more resources and staff }\end{array}$ \\
\hline 5. & Political issues & $\begin{array}{l}1.14 . \\
1.15 . \\
1.16 . \\
1.17\end{array}$ & $\begin{array}{l}\text { Increase benefits and packages } \\
\text { Expand age benefits } \\
\text { Initiates new jobs and opportunities } \\
\text { Change strategies and policies }\end{array}$ \\
\hline 6. & Growth in unemployment & $\begin{array}{l}1.18 . \\
1.19 . \\
1.20 . \\
1.21 \\
1.22\end{array}$ & $\begin{array}{l}\text { Add more assistance funds and benefits } \\
\text { Change strategies and policies } \\
\text { Social and cultural problems } \\
\text { Decrease government funds } \\
\text { Change management and executives }\end{array}$ \\
\hline 7. & Coordination & $\begin{array}{l}1.23 \\
1.24 \\
1.25 \\
1.26\end{array}$ & $\begin{array}{l}\text { Upgrade systems } \\
\text { Improve business processes } \\
\text { Adopt new technologies } \\
\text { Standardise regulations and polies }\end{array}$ \\
\hline 8. & Service and users' growth & $\begin{array}{l}1.27 . \\
1.28 .\end{array}$ & $\begin{array}{l}\text { Expand and upgrade systems } \\
\text { Change policies and strategies }\end{array}$ \\
\hline 9. & Quality of services & 1.29 . & Upgrade and Improve the systems \\
\hline 10. & Management change & $\begin{array}{l}1.30 . \\
1.31 \\
1.32\end{array}$ & $\begin{array}{l}\text { Change policies and systems } \\
\text { Require new knowledge and experience } \\
\text { Change program }\end{array}$ \\
\hline 11. & Technology Dynamics & $\begin{array}{l}1.33 . \\
1.34 .\end{array}$ & $\begin{array}{l}\text { Change and develop systems } \\
\text { Upgrade }\end{array}$ \\
\hline 12. & Management Control & $\begin{array}{l}1.35 . \\
1.36 . \\
1.37 . \\
1.38 . \\
1.39 . \\
1.40 . \\
1.41 . \\
1.42 .\end{array}$ & $\begin{array}{l}\text { Modify Payment Policy } \\
\text { Modify Account Information } \\
\text { Create New Account } \\
\text { Modify Payment Business Process } \\
\text { Modify Deduction Rules } \\
\text { Create New Policies } \\
\text { Modify Deduction Process } \\
\text { Rollback Deduction and Penalties }\end{array}$ \\
\hline
\end{tabular}


8.1.11. Table 14: Hafiz's Business Process Change Alternative Scenarios Consolidation and Voting Documentation

\begin{tabular}{|c|c|c|c|c|c|}
\hline Name & Scenarios & Member & Action & Voting & Result \\
\hline BPCA1 & Expand age benefits & $\mathrm{CCM}$ & Joined & $6 / 6$ & Accepted \\
\hline BPCA2 & Increase the period of benefits & HPM & Joined & $6 / 6$ & Accepted \\
\hline ВРCA3 & Increase benefits and packages & $\mathrm{DM}$ & Joined & $5 / 6$ & Accepted \\
\hline BPCA4 & Increase training programs & EA & Joined & $6 / 6$ & Accepted \\
\hline BPCA5 & Initiates new jobs and opportunities & HPM & Joined & $4 / 6$ & Accepted \\
\hline BPCA6 & Decrease government income & BPM & Joined & $3 / 6$ & Accepted \\
\hline BPCA7 & Cutting budget from Hafiz Program & HPM & Joined & $3 / 6$ & Accepted \\
\hline BPCA8 & Increase wages & $\mathrm{CCM}$ & Joined & $3 / 6$ & Accepted \\
\hline BPCA9 & Modify Payment Policy & BD & Joined & $4 / 6$ & Accepted \\
\hline BPCA10 & Modify Account Information & BPM & Joined & $3 / 6$ & Accepted \\
\hline BPCA11 & Create New Account & $\mathrm{DM}$ & Joined & $3 / 6$ & Accepted \\
\hline BPCA12 & Modify Payment Business Process & EA & Joined & $3 / 6$ & Accepted \\
\hline BPCA13 & Modify Deduction Rules & $\mathrm{BD}$ & Joined & $3 / 6$ & Accepted \\
\hline BPCA14 & Create New Policies & HPM & Joined & $3 / 6$ & Accepted \\
\hline BPCA15 & Modify Deduction Process & EA & Joined & $4 / 6$ & Accepted \\
\hline BPCA17 & Rollback Deduction and Penalties & $\mathrm{CCM}$ & Joined & $3 / 6$ & Accepted \\
\hline BPCA18 & Change program & BD & Joined & $2 / 6$ & Accepted \\
\hline BPCA19 & Improve business processes & BPM & Joined & $3 / 6$ & Accepted \\
\hline BPCA20 & Change and improve policies & $\mathrm{DM}$ & Joined & $3 / 6$ & Accepted \\
\hline BPCA21 & Upgrade and improve the systems & EA & Joined & $3 / 6$ & Accepted \\
\hline BPCA22 & Adopt new technologies & $\mathrm{BD}$ & Joined & $2 / 6$ & Accepted \\
\hline BPCA23 & Add more resources and staff & HPM & Joined & $2 / 6$ & Accepted \\
\hline BPCA24 & Use outsourcing & EA & Joined & $1 / 6$ & Accepted \\
\hline BPCA25 & $\begin{array}{l}\text { Require new knowledge and } \\
\text { experience }\end{array}$ & $\mathrm{CCM}$ & Joined & $1 / 6$ & Accepted \\
\hline
\end{tabular}

\subsubsection{Table 15: Hafiz Mangers' Voting Weights}

\begin{tabular}{lcc}
\hline Position & Abbreviation & Voting Weight \\
\hline Hafiz Program Manager & HPM & 5 \\
Change and Configuration Manager & CCM & 5 \\
Development Manager & DM & 4 \\
Business Process Manager & BPM & 4 \\
Business Development Manager & BD & 3 \\
Enterprise Architect & EA & 3 \\
\hline
\end{tabular}


8.1.13. Table 16: Hafiz Mangers' Voting and Prioritisation Scenarios Documentation

\begin{tabular}{lccccccc}
\hline \multicolumn{1}{c}{ Position } & HMP & CCM & DM & BPM & BD & EA & Aggregate Vote \\
\hline Scenario & & & & & & & \\
\hline Increase training programs & 10 & 15 & 8 & 8 & 6 & 6 & 53 \\
Increase benefits and packages & 15 & 10 & 8 & 12 & 6 & 0 & 51 \\
Increase the period of benefits & 10 & 8 & 8 & 12 & 9 & 9 & 56 \\
Expand age benefits & 15 & 10 & 12 & 12 & 6 & 6 & 61 \\
Initiates new jobs and opportunities & 10 & 5 & 8 & 8 & 9 & 9 & 49 \\
Decrease government income & 10 & 10 & 8 & 0 & 0 & 0 & 28 \\
\hline
\end{tabular}

\subsection{Organisational Change Management Drivers \& Business Process Scenarios Documentation Template}

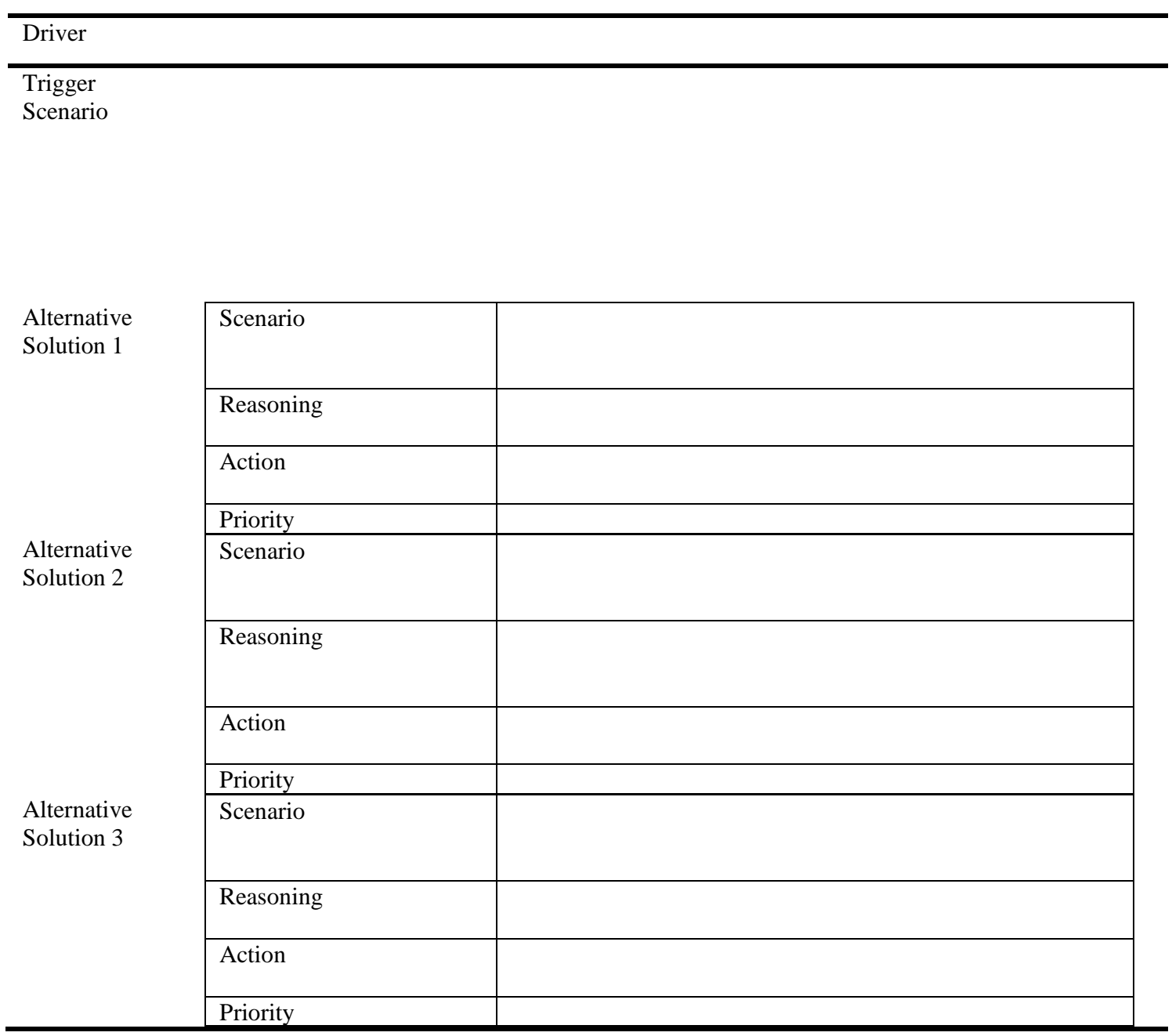


8.3. Business Process Modelling Notation Scenarios Representation Template

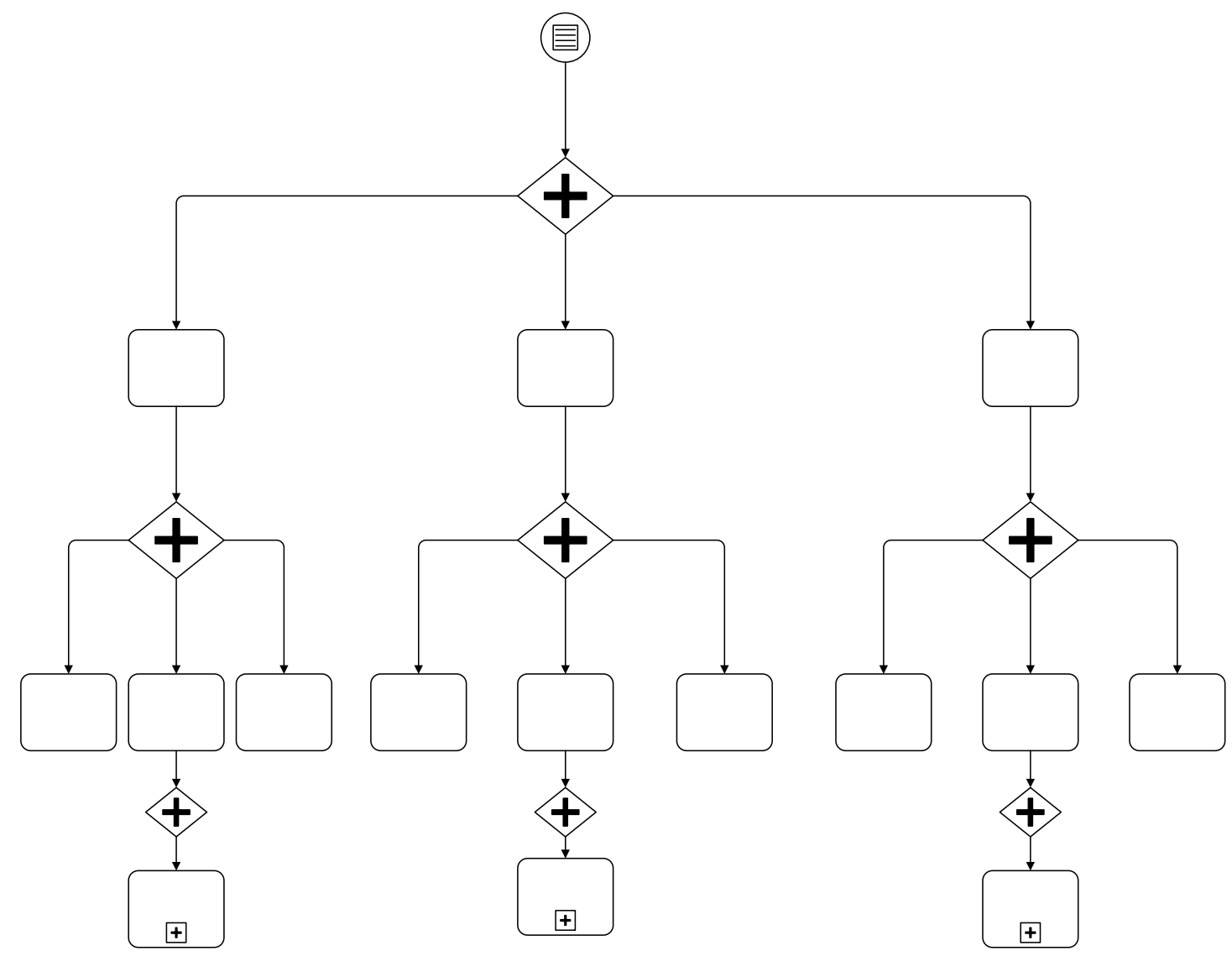

\subsection{Hafiz Organisational Structure}

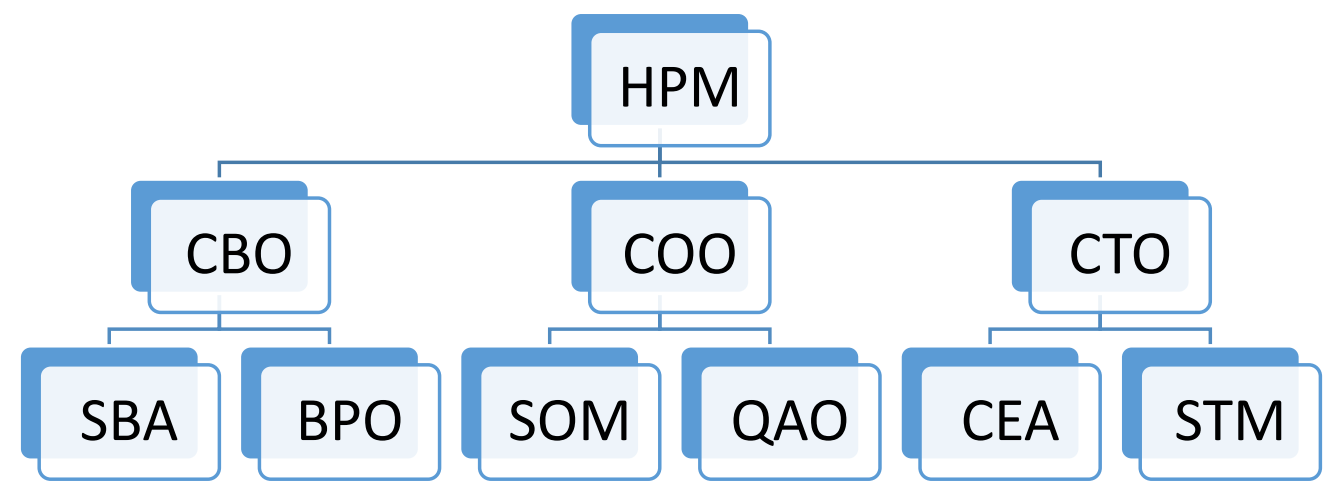




\subsection{Hafiz Functional Structure}

\begin{tabular}{|c|c|c|c|c|c|c|}
\hline & & & $\begin{array}{c}\text { Hafiz's } \\
\text { Functional } \\
\text { Structure }\end{array}$ & & & \\
\hline$\Gamma$ & $T$ & $T$ & & $T$ & $T$ & \\
\hline $\begin{array}{l}\text { Application } \\
\text { Processing }\end{array}$ & $\begin{array}{l}\text { Data } \\
\text { Analysis }\end{array}$ & Control & Training & Coordination & $\begin{array}{l}\text { Payment } \\
\text { Processing }\end{array}$ & Reporting \\
\hline
\end{tabular}

\subsection{Glossary/Acronyms}

8.6.11. General

\begin{tabular}{ll}
\hline Terminology & Description \\
\hline BPC & Business Process Change \\
BPCD & Business Process Change Decision \\
BPMN & Business Process Modelling Notation \\
CAM & Causal Analysis Model \\
CM Team & Change Management Team of the Hafiz Program, case study \\
HCMS & Hierarchical Change Management Structure \\
HEW & Hierarchical Change Management Structure Elicitation Workshop \\
OPM & Organisation Performance Measurement \\
\hline
\end{tabular}

\subsubsection{Case Study Workshop Terminology}

\begin{tabular}{ll}
\hline Terminology & Description \\
\hline BPMO & Business Process Management Officer \\
BPP & Beneficiary Payment Processing \\
BTP & Beneficiary Training Process \\
CAP & Candidate Approval Process \\
CAPS & Candidate Application Processing System \\
CBO & Chief Business Officer \\
CEA & Chief Enterprise Architect \\
CEP & Candidate Evaluation Process \\
CIP & Coordination \& Integration Platform \\
CMP & Complaints Management Process \\
COO & Chief Operation Officer \\
CRP & Candidate Registration Process \\
CTO & Chief Technology Officer \\
DPP & Deduction \& Penalty Processing \\
DRP & Dispute Resolution Process \\
ESIR & Enhance Students Ineligibility Reason \\
FI & Financial Incentives (to encourage job seeking) \\
\hline
\end{tabular}




\begin{tabular}{|c|c|}
\hline Terminology & Description \\
\hline GOSIP & GOSI Coordination Process \\
\hline HJSE & Help Job Seekers to find Employment \\
\hline HMP & Hafiz Main Portal \\
\hline HPM & Hafiz Program Manager \\
\hline JMP & Job Matching Processing \\
\hline MCIP & MCI Coordination Process \\
\hline $\mathrm{MCP}$ & Monitoring and Controlling Process \\
\hline MCS & Monitoring \& Control System \\
\hline MFP & MOF Coordination Process \\
\hline MHEP & MOHE Coordination Process \\
\hline MIP & MOI Coordination Process \\
\hline MLP & MOL Coordination Process \\
\hline OCP & Organisation Coordination Process \\
\hline PPS & Payment Processing System \\
\hline QAO & Quality Assurance Officer \\
\hline RDP & Report \& Data Analysis Platform \\
\hline RMP & Report Management Process \\
\hline RUP & Resolve Unemployment Problem \\
\hline SBA & Senior Business Architecture \\
\hline SOM & Senior Operation Manager \\
\hline STM & Senior Technology Manager \\
\hline TBMD & Provide Training to Bridge Market Demand \\
\hline TMS & Training Management System \\
\hline
\end{tabular}

\subsubsection{Business Process Alternatives}

\begin{tabular}{ll}
\hline Terminology & Description \\
\hline AAP & Auto Append Policy \\
ACD & Auto Change Deduction \\
ACP & Auto Change Policy \\
ACR & Auto Change Repository \\
ADP & Auto Deduction Process \\
ADT & Auto Delete Transaction \\
ANA & Auto New Account \\
AOP & Append Old Policy \\
APC & Auto Policy Creation \\
APP & Amend Payment Protocol \\
APR & Amend Policy Rules \\
APS & Auto Payment Sub-module \\
ARP & Auto Replace Policy \\
ART & Auto Rollback Transaction \\
BPD & Business Process Driven \\
\hline
\end{tabular}




\begin{tabular}{|c|c|}
\hline Terminology & Description \\
\hline $\mathrm{CDP}$ & Change Deduction Process \\
\hline $\mathrm{CDR}$ & Change Deduction Rules \\
\hline CNA & Create New Account \\
\hline CNP & Create New Policies \\
\hline CPG & Change Payment Gateway \\
\hline CPP & Change Payment Protocol \\
\hline CPR & Change Policy Repository \\
\hline CPS & Change Payment Sub-module \\
\hline DTL & Delete Transaction Log \\
\hline ECW & Execute Callback Web service \\
\hline INA & Insert New Account \\
\hline INP & Insert New Policy \\
\hline MAI & Modify Account Information \\
\hline MAP & Manual Append Policy \\
\hline MBA & Modify Bank Account \\
\hline MCD & Manual Change Deduction \\
\hline $\mathrm{MCP}$ & Manual Change Policy \\
\hline MCR & Manual Change Repository \\
\hline MDM & Manual DB Modification \\
\hline MDP & Modify Deduction Process \\
\hline MDR & Modify Deduction Rules \\
\hline MDT & Manual Delete Transaction \\
\hline MLA & Modify Local Account \\
\hline MNA & Manual New Account \\
\hline MPB & Modify Payment Business Process \\
\hline MPP & Modify Payment Policy \\
\hline MPS & Manual Payment Sub-module \\
\hline MRP & Manual Replace Policy \\
\hline RDP & Rollback Detection and Penalties \\
\hline ROP & Replace Old Policy \\
\hline $\mathrm{RPC}$ & Radical Payment Change \\
\hline RTM & Rollback Transaction Manager \\
\hline
\end{tabular}

